\title{
EL SOBERANO SEGÚN EL CONSTITUCIONALISMO INDEPENDENTISTA NEOGRANADINO: ¿EL PUEBLO CATÓlICO O LA NACIÓN CATÓlICA? *
}

\section{THE SOVEREIGN ACCORDING TO COLOMBIAN INDEPENDENCE CONSTITUTIONALISM: THE CATHOLIC PEOPLE OR THE CATHOLIC NATION?}

\author{
Andrés Botero \\ Universidad Industrial de Santanter
}

\begin{abstract}
SUMARIO: I. INTRODUCCIÓN. II. EL SOBERANO DURANTE LA PRIMERA REPÚBLICA. III. LA CONVENIENCIA DE LA ALUSIÓN AL PUEBLO EN VEZ DE LA NACIÓN. IV. APARICIÓN DE LA NACIÓN COMO SOBERANO. V. EL PUEBLONACIÓN CATÓLICO. VI. PUEBLO CATÓLICO Y CIUDADANO PROPIETARIO. VII. LA NACIÓN-PUEBLO CATÓLICO Y LA MODERNIDAD. VIII. CONCLUSIONES.
\end{abstract}

Resumen: En este texto se señalan las diferencias y las similitudes entre los conceptos de soberanía usados en el mundo constitucional hispanoamericano, con énfasis en el caso neogranadino, entre 1811 y 1815: pueblo católico y nación católica. Las diferencias más significativas fueron: (i) considerar al pueblo católico como el soberano permitió la expresión de los intereses locales y familiares que tanto dominaron el constitucionalismo provincial de la Primera República y (ii) acudir al pueblo católico como soberano era una forma de oponerse al concepto de nación católica usado por las Cortes y la Constitución de Cádiz, que fue la contraparte bélica durante los primeros años de la Revolución de Independencia. Ya, una vez derrotada la Primera República neogranadina, los afanes del nuevo tipo de guerra y los aprendizajes ante los errores políticos, llevaron a que apareciera con fuerza entre los revolucionarios el concepto de nación (católica) como el nuevo soberano, lo que permitió un proyecto de identidad colectiva, más allá de lo local, entre los independentistas, proyecto ausente en el constitucionalismo provincial de la Primera República. Entonces, cuando la Revolución de Independencia asumió el discurso de soberanía nacional tanto en el mundo constitucional como en el militar, es que se pudieron superar las distancias locales e incluso familiares entre los revolucionarios, favoreciendo así

\footnotetext{
* Este trabajo es una importante reconstrucción crítica de dos textos anteriores, muy similares entre sí. El primero publicado en: Botero, Andrés, "El pueblo católico criollo como un poder soberano en la Constitución antioqueña de 1812" en José Ramón Narvaez y Emilio Rabasa (edits.), Problemas actuales de la historia del derecho en México, Porrúa y Tecnológico de Monterrey, México, 2007, pp. 287-314. El segundo en: Botero, Andrés, Modelo de lectura del constitucionalismo provincial hispanoamericano: origen del constitucionalismo antioqueño, Universidad de Medellín, Medellín, 2010, pp. 200-221. Los cambios más relevantes son: i) se amplía el horizonte de análisis, incluyendo en el nuevo texto las constituciones provinciales neogranadinas y no solo las de Antioquia; ii) se agregan nuevos elementos ausentes en los textos previos sobre cómo entender el paso del concepto de pueblo al de nación, en especial lo atinente a la mutación de la doctrina militar; iii) se reorganiza el orden de los argumentos; y iv) se mejora y se actualiza el apartado bibliográfico. Por tanto, se trata de escritos cercanos pero diferentes.
} 
un proyecto aglutinador exitoso. Entonces, el nacionalismo soberano no fue un discurso aceptado en la Independencia temprana, sino uno construido por los afanes de la guerra y la política, una vez fueron desechadas las constituciones provinciales de la Primera República.

Abstract: This paper points out the differences and similarities between the concepts of sovereignty used in the Hispanic American world, with emphasis on the Neogranadin case, between 1811 and 1815: Catholic people and Catholic nation. The most significant differences were: (i) to consider the Catholic people as the sovereign allowed the expression of local and family interests that dominated the provincial constitutionalism of the First Republic and (ii) to approach the Catholic people as sovereign was a way to oppose to the concept of a Catholic nation used by the Cortes and the Constitution of Cadiz in Spain, which was the warlike counterpart during the first years of the Revolution of Independence. Already, once defeated the First Republic, the rules of the new type of war and the apprenticeships of the political errors, led that appeared between the revolutionaries the concept of (catholic) nation as the new sovereign, which allowed a project of collective identity, beyond the local, among the "independentistas", project absent in the provincial constitutionalism of the First Republic. Then, when the Revolution of Independence assumed the discourse of national sovereignty in both the political and military worlds, it was that the local and even family distances between the revolutionaries could be overcome, thus favoring a successful agglutinative project. So sovereign nationalism was not a discourse accepted in early Independence, but one built by the pursuits of war and constitutional politics, once the provincial constitutions of the First Republic were discarded.

Palabras clave: Nación, pueblo, soberanía, constituciones de independencia, Nueva Granada.

Key Words: Nation, people, sovereignty, constitutions of independence, New Granada.

"A pátria que quisera ter era um mito; era um fantasma criado por ele no silêncio do seu gabinete. Nem a fisica, nem a moral, nem a intelectual, nem a politica que julgava existir, havia"1.

\section{i. INTRODUCCIÓN}

En escritos anteriores ${ }^{2}$ se ha hecho referencia al concepto de "pueblo católico" como el sujeto político soberano por excelencia en el proceso constituyente neogranadino de la Primera República (1811-1815), a partir de un confuso maridaje constitucional que se dio entre individualismo, estatalismo, liberalismo, ilustración, escolasticismo, etc. En cambio, el concepto de "nación

\footnotetext{
${ }^{1}$ Lima Barreto, Afonso, Triste fim de Policarpo Quaresma (1911), Ática, São Paulo, 2004, p. 175.

2 Botero, Andrés, Modelo de lectura del constitucionalismo provincial hispanoamericano: origen del constitucionalismo antioqueño, op. cit., pp. 200-221.
} 
católica", como sujeto soberano, apareció con fuerza entre los defensores del régimen gaditano, de un lado, y entre los revolucionarios neogranadinos independentistas durante la Segunda República (a partir de 1819-1821), del otro.

Aquí cabe preguntar a qué se debió ese cambio del discurso sobre el poder soberano entre la Primera y la Segunda República. La respuesta, si se permite ser algo amplio por el momento, pasa por tres ejes: i) el concepto de "pueblo" era más acorde con las redes clientelistas, familiares y locales que querian regir los destinos de la Primera República; ii) para evitar malentendidos politicos con la "nación española" -que identificaba a la Monarquía ${ }^{3}-\mathrm{y}$, en especial, con la "nación española bihemisférica" -consagrada en las Cortes y en la Constitución de Cádiz de $1812^{4}$-, fue preferible aludir a un "pueblo provincial católico" como el motor soberano; y iii) la guerra, ideológicamente, sostenida durante la Primera República se vivió de forma muy diferente a como lo fue durante la Segunda, en especial porque durante aquella se concibió como una "guerra cívica tradicional" y no como una "guerra nacional moderna" como fue en esta, por lo que el discurso de nación apenas se mencionaba durante los años 1811-1815. Luego se pasará a explicar, detalladamente, cada uno de estos tres aspectos.

Finalmente, una aclaración formal. Se han actualizado los textos de la época a las reglas ortográficas contemporáneas, asunto que no afecta, para nada, su comprensión.

\section{EL SOBERANO DURANTE LA PRIMERA REPÚBLICA}

Antes que nada, es importante resaltar que, según Chiaramonte ${ }^{5}$, en el uso del concepto "nación" en este período histórico (finales del siglo XVIII y primera mitad del siglo XIX), quedó en evidencia una mutación de su significado, en tanto se pasó, paulatinamente, de la nación entendida en un sentido étnico diferenciador (como era propio en el Antiguo Régimen') a uno político aglutinador

3 Wasserman, Fabio, "El concepto de nación y las transformaciones del orden politico en Iberoamérica, 1750-1850”, en Javier Fernández Sebastián (Dir.), Diccionario politico y social del mundo iberoamericano, La era de las revoluciones, 1750-1850, Iberconceptos I, Fundación Carolina y otros, Madrid, 2009, p. 855.

4 Artículo 1 de la Constitución gaditana: "La Nación española es la reunión de todos los españoles de ambos hemisferios". Claro está que el concepto político -y no étnico- de "nación española" no provino de Cádiz, sino de antes, en un largo trasegar que va desde la separación establecida por la Ilustración hispana entre "nación" (que sería la metrópoli peninsular) y "monarquia" (que abarcaria los territorios ultramarinos), hasta la identificación que hizo la constitución gaditana de dichos términos en el marco de la reunión de los "dos hemisferios". Cfr. Portillo Valdés, José Maria, "Cuerpo de nación, pueblo soberano. La representación politica en la crisis de la monarquía hispana", Ayer, No. 61, 2006, pp. 47-76. Portillo Valdés, José María. "Nación - España", en Javier Fernández Sebastián (Dir.), Diccionario politico y social del mundo iberoamericano, La era de las revoluciones, 1750-1850, Iberconceptos I, Fundación Carolina y otros, Madrid, 2009, pp. 919-928.

${ }^{5}$ Chiaramonte, José Carlos, Nación y Estado en Iberoamérica. El lenguaje político en tiempos de la independencia, Sudamericana, Buenos Aires, 2004, pp. 11-33.

6 La expresión nación, para referirse al encasillamiento de individuos según grupos étnicos, dentro del marco común de la res publica christiana, se evidenció en el Medioevo europeo, especialmente en los campus universitarios de la época (Bolonia, París, Montpellier, etc.), donde coincidieron estudiantes de diversos orígenes. Como estudiante, se pertenecía a una nación por el origen, y a una patria por el suelo natal y sus vínculos familiares. La "nación" era una forma de atribución demográfica y etnográfica, mas no política. El concepto propiamente político era 
(más acorde con la Modernidad); es decir, se pasó de la nación como conjunto de personas unidas por una identidad étnica general (v.gr. americano ${ }^{7}$ ) o particular (v.gr. neogranadino ${ }^{8}$, indígena, etc.) que buscaban su distinción de otros grupos ubicados en el mismo espacio y tiempo, a la nación como un grupo de personas unidas por su sujeción a una misma Constitución, por lo que repelen cualquier autoridad diferente a su propio gobierno, según las ideas contractualistasiusnaturalistas que se sumaron y modificaron las ideas dominantes a finales de la Colonia, como la escolástica. Dicho sea de paso, aquí se parte de una postura mediadora entre la corriente "liberal" y la "revisionista", siendo los primeros los que hacen hincapié en el liberalismo y la Ilustración, y los segundos en la Segunda Escolástica, al momento de responder sobre el fundamento conceptual de la Independencia 9 . Y es mediadora porque ambas fuentes se dieron cita, apoyándose, corrigiéndose, enfrentándose, en una época tan compleja por la infinidad de actores e intereses que se dieron cita. Por tanto, sólo puede comprenderse la extraña confluencia de todas estas posturas en el constitucionalismo hispanoamericano si se reconoce dicha tensión en la base misma de lo constitucional ${ }^{10}$.

Pero volviendo sobre el tópico del presente artículo, la noción étnica del concepto "nación" retornó a escena con la irrupción del "romanticismo" en el escenario politico hispanoamericano, aproximadamente con posterioridad a 1830,

"pueblo" es decir, el conjunto de familias de una ciudad o reino. Cfr. Bandieri, Luis Maria, "Patria, Nación, Estado et quibusdam aliis", Revista Facultad de Derecho y Ciencias Políticas, vol. 37, n. 106,2007, p. 8. Wasserman, Fabio, "El concepto de nación y las transformaciones del orden político en Iberoamérica, 1750-1850", op. cit., pp. 852-854.

7 Feres Junior, João, “El concepto de América: ¿concepto básico o contraconcepto?”, en Javier Fernández Sebastián (Dir.), Diccionario politico y social del mundo iberoamericano, La era de las revoluciones, 1750-1850, Iberconceptos I, Fundación Carolina y otros, Madrid, 2009, pp. 54-55.

8 König, Hans-Joachim, "Nación - Colombia", en Javier Fernández Sebastián (Dir.), Diccionario politico y social del mundo iberoamericano, La era de las revoluciones, 1750-1850, Iberconceptos I, Fundación Carolina y otros, Madrid, 2009, p. 908.

9 Cfr. Lomné, Georges, "De la "república" y otras repúblicas: la regeneración de un concepto", en Javier Fernández Sebastián (Dir.), Diccionario politico y social del mundo iberoamericano, La era de las revoluciones, 1750-1850, Iberconceptos I, Fundación Carolina y otros, Madrid, 2009, pp. 12531254.

10 Como prueba de la influencia escolástica en el constitucionalismo neogranadino se encuentra la constante remisión normativa al catolicismo, así como los argumentos esgrimidos (como el del pactum subjectionis, el cual fue considerado por los revolucionarios como roto) para defender la Independencia. Véase: Gardinetti, Juan Paulo, La revolución criolla: surgimiento y desarrollo de las instituciones argentinas en la etapa revolucionaria (1810-1815), Universidad Nacional de la Plata, La Plata, 2006, pp. 25-28. Varela Suanzes, Joaquín, La teoría del Estado en los orígenes del constitucionalismo hispánico (las Cortes de Cádiz), Centro de Estudios Constitucionales, Madrid, 1983. Jaramillo Uribe, Jaime, El pensamiento colombiano en el siglo XIX, Planeta, Bogotá, 1996, pp. 333-340. Pérez Collados, José Maria, "La recepción de los principios politicos de la ilustración en la Nueva España", en Homenaje al profesor Alfonso GarcíaGallo, tomo III, volumen 2, Universidad Complutense, Madrid, 1996, pp. 227-259 (especialmente: pp. 238-253); etc. Pero también muchos de los constituyentes independentistas no dejaban de criticar el escolasticismo a partir de los nuevos modelos mundializados, como la Ilustración: el 25 de enero de 1808, Camilo Torres (quien poco después lideraría los movimientos federalistas en la Nueva Granada) presentó un informe reprobando el plan de estudios presentado para la fundación de un Colegio Franciscano de Medellín, al considerarlo como "muy escolástico, partidista y tradicional" (Restrepo Toro, Hernando, "La educación superior", en Jorge Orlando Melo, Historia de Antioquia, Presencia, Bogotá, 1998, p. 367). 
para leer bajo dicho lente étnico, entre otras cosas, el proceso de Independencia, asunto del que no se hablará en tanto se escapa del objeto de investigación ${ }^{11}$. Pero más allá de esta claridad sobre el cambio en el uso del concepto "nación", hay algo claro que no se puede perder de vista: salvando algunos casos en los cuales se usaron los términos "nación" y "pueblos" como si fuesen idénticos, a diferencia de España, en la Nueva Granada se prefirió en los textos constitucionales de la Primera República el uso del concepto de "pueblo" como el poder soberano por excelencia.

Resulta que para las ideas contractualistas de la época del primer constitucionalismo hispanoamericano, el fundamento de la sociedad política radicaba en el llamado "contrato social". Para dar un ejemplo, se puede leer en la Constitución antioqueña de 1812 , en sus preliminares ${ }^{12}$ :

Los representantes de la Provincia de Antioquia en el Nuevo Reino de Granada, plenamente autorizados por el pueblo, para darle una Constitución que garantice a todos los ciudadanos su Libertad, Igualdad, Seguridad y Propiedad: convencidos de que abdicada la Corona, reducidas a cautiverio, sin esperanza de postliminio las personas que gozaban el carácter de soberanas, disuelto el Gobierno que ellas mantenian durante el ejercicio de sus funciones, devueltas a los españoles de ambos hemisferios las prerrogativas de su libre naturaleza, y a los pueblos las del Contrato Social, todos los de la nación, y entre ellos el de la Provincia de Antioquia, reasumieron la soberania, y recobraron sus derechos...

Estos preliminares ponen en evidencia dos tensiones constitucionales: la primera derivada de la recepción e implementación de diversas posturas, tales como el iusnaturalismo individualista que propuso una soberanía popular derivada de un contrato social entre hombres libres, y el escolasticismo que argumentó que desaparecido el soberano-rey en acto, debía reasumir el poder el soberano en potencia, esto es, el pueblo ${ }^{13}$, que, para el caso neogranadino, sería la Provincia en su sede de gobierno más concreta: un colegio criollo que representaba los intereses de los cabildos y de las familias que en ellos han solido dominar. La segunda, de un "pueblo" provincial que reasumió la soberanía otrora de la "nación española", soberanía que se creyó estaba perdida con ocasión del vacío de poder generado por la invasión napoleónica de la Península ${ }^{14}$.

11 Cfr. Wasserman, Fabio, "El concepto de nación y las transformaciones del orden político en Iberoamérica, 1750-1850”, op. cit., pp. 868-869.

12 Constitución del Estado de Antioquia, sancionada por los representantes de toda la provincia y aceptada por el pueblo el 3 de mayo del año de 1812, Imprenta de D. Bruno Espinosa por D. Nicomedes Lora, Bogotá, 1812.

13 Sobre la tesis escolástica de la soberania del pueblo, ver: Carpintero, Francisco, "Los escolásticos españoles en los inicios del liberalismo político y jurídico", Revista de Estudios Histórico-Jurídicos, Sección Historia del Pensamiento Jurídico, no. XXV, 2003, pp. 341-373 (especialmente, p. 347).

14 Fue común entre los criollos rebeldes, entre 1810 y 1812 , considerar que la "nación española" estaba perdida ante Napoleón. Por ejemplo, en la Arenga del Teniente Gobernador, Joaquín de Caycedo y Cuero, ante el Cabildo de Santiago de Cali, del 3 de julio de 1810, se puede leer: “¿Y no se rendirá Cádiz? Pluguiese el cielo que no, pero quien sabe si en el primer correo maritimo llega el colmo de nuestras desgracias y se anuncia ya entregada ¡Ya no hay fuerzas para resistir un poder colosal como el de Bonaparte! Ya la nación está agonizante". Transcrito en Quintero, Inés y Martínez, Armando, Actas de formación de juntas y declaraciones de independencia (1809-1822), Tomo I, UIS, Bucaramanga, 2008, p. 280. 
Igualmente, dicha tensión se puede evidenciar en la Constitución antioqueña de 1815, que señaló en la "Proclamación de los derechos del hombre en sociedad", artículo 21: "El contrato social es el más sagrado de todos los contratos, y obliga mutuamente a los súbditos y superiores, no solo delante de los hombres sino también delante de Dios".

Según el contractualismo, de este "contrato social" participarian los hombres libres e iguales, decidiendo asociarse en una comunidad politica (para el caso que se estudia, en los Estados provinciales) apoyada en los designios divinos sobre un pueblo ahora soberano. Pero en verdad, según lo expone Chiaramonte, esta voluntad individual recayó sobre las provincias y éstas a su vez en los cabildos o juntas, siendo sus integrantes quienes, instaurados como colegios electorales o constituyentes, acordaron con otras provincias o juntas conformar una República ${ }^{15}$ y un Estado, pues "tal parece que en la América hispana, el acto de imaginar la nación pasaba primero por imaginar el Estado"16. De esta manera, el fundamento y la legitimidad predicados a las nuevas constituciones republicanas, según el contractualismo hispanoamericano, no era tanto el de una "nación" ora en su sentido étnico, ora en su sentido político, como sí el de un "pueblo" fruto de un acuerdo político (derivado de la soberanía popular), es decir, del contrato social, pero en tensión con otras ideas dominantes en la época ${ }^{17}$.

No obstante, fuera del marco constitucional, el concepto de "nación" subsistió de alguna manera, especialmente cuando se hacía referencia a las castas. Aunque existían excepciones ${ }^{18}$, la regla general de la sociedad colonial que heredó la República, fue la de una fuerte relación entre casta y procedencia étnica. Así, no era difícil observar la alusión de "americano" para designar de

15 Las provincias neogranadinas se autodenominaron rápidamente como Repúblicas, a diferencia de lo sucedido en otros países hispanoamericanos (Cfr. Lomné, Georges, "De la "república" y otras repúblicas: la regeneración de un concepto", op. cit., especialmente, p. 1254 y 1260). El concepto de República tuvo un desarrollo ambiguo en Iberoamérica, pero hubo una constante de identificar dicho término, durante la Independencia, con el rechazo a la Monarquía; sin olvidar que el uso de dicho concepto se vio favorecido por el pasado mítico al que todos citaban en aquel entonces (la Roma republicana) y como forma de articularse con las revoluciones estadounidense y francesa. Cfr. Lomné, Georges, “República - Colombia”, en Javier Fernández Sebastián (Dir.), Diccionario político y social del mundo iberoamericano, La era de las revoluciones, 1750-1850, Iberconceptos I, Fundación Carolina y otros, Madrid, 2009, pp. 1306-1320. Botero, Andrés, Modelo de lectura del constitucionalismo provincial hispanoamericano: origen del constitucionalismo antioqueño, op. cit., pp. 69-84.

16 Almario, Oscar, "Del nacionalismo americano en las Cortes de Cádiz al independentismo y nacionalismo de Estado en la Nueva Granada, 1808-1821", en Manuel Chust, e Ivana Frasquet (edit.), Los colores de las independencias iberoamericanas: liberalismo, etnia y raza, Consejo Superior de Investigaciones Científicas, Madrid, 2009, p. 213. Esto explica la continuidad de las instituciones del cabildo y del ayuntamiento en las primeras Constituciones hispanoamericanas. Para Venezuela, dice López: "Se trataba del ejercicio de la soberanía por parte del común expresada en el Ayuntamiento" (López Bohórquez, Ali Enrique, "Viejas instituciones para una nueva república: El caso de Venezuela (1810-1830)", Revista de Historia del Derecho, n 32, 2004. p. 138).

17 Sá e Melo Ferreira, Fátima, "Entre viejos y nuevos sentidos: "pueblo" y "pueblos" en el mundo iberoamericano entre 1750 y 1850", en Javier Fernández Sebastián (Dir.), Diccionario politico y social del mundo iberoamericano, La era de las revoluciones, 1750-1850, Iberconceptos I, Fundación Carolina y otros, Madrid, 2009, pp. 1125-1135.

18 Descritas por Peralta, Jaime Andrés, Los novatores: la cultura ilustrada y la prensa colonial en Nueva Granada (1750-1810), Editorial Universidad de Antioquia, Medellin, 2005. pp. 35-36. 
manera general a las castas, en especial a indigena ${ }^{19}$, o incluso un uso más particular: "Es el sentido con que en América, por ejemplo, todavía en el siglo XIX se distinguian los grupos de esclavos africanos por "naciones": la "nación" guinea, la "nación" congo, así como también se lo encuentra aplicado a las diversas "naciones indigenas"20.

Por tanto, a diferencia del Viejo Continente, en los textos del constitucionalismo provincial neogranadino y en diferentes manifiestos políticojurídicos se encontraron, con preferencia al concepto de "nación" como fundamento del "contrato social", el concepto politico de "pueblo"21, que constituía la "República"22 y la "patria"23. ¿Por qué? Podría pensarse, a primera vista, que la mención al "pueblo" implicó un reconocimiento jurídico y político del individualismo jacobino como el fundamento constitucional. Incluso, no faltaron documentos que miraban con buenos ojos al Directorio. Recuérdese los debates revolucionarios franceses entre los partidarios de la idea de soberanía nacional, que defendieron una unidad soberana más allá de los individuos componentes, y los seguidores de una concepción de soberanía popular, que hablaron de una soberanía del pueblo entendido éste como una sumatoria de individuosciudadanos por lo que los integrantes eran depositarios de un poder que se sumaba y que limitaba de alguna manera al naciente Estado ${ }^{24}$.

19 Feres Junior, João, “El concepto de América: ¿concepto básico o contraconcepto?”, op. cit., pp. 59-62.

${ }^{20}$ Chiaramonte, José Carlos, Nación y Estado en Iberoamérica. El lenguaje politico en tiempos de la independencia, op. cit., p. 40. Wasserman, Fabio, "el concepto de nación y las transformaciones del orden político en Iberoamérica, 1750-1850”, op. cit., pp. 853-856.

En el lenguaje popular argentino, hasta bien entrado el siglo XIX, "nación" era el nacido en el extranjero o el indio, por oposición al paisano o hijo del país. Además, en la época de Rosas, los negros se agrupaban por sí mismos en "naciones", según la región de África de donde fuesen originarios. En el "Martín Fierro", libro canónico de la cultura popular argentina, se narra en la primera parte, publicada en 1872, el incidente que tiene el protagonista, llevado como soldado de leva a la "frontera" con los indios, con otro soldado, de origen napolitano, de resultas del cual "quedó en su puesto el nación/y yo fi al estaquiadero"; es decir, el napolitano se quedó como centinela, mientras el gaucho fue sometido a la estaqueada, donde se lo ataba de pies y manos a cuatro estacas, manteniéndose durante horas los miembros en extrema tensión. Hernández, José, "Martín Fierro", en Martín Hernández et. al., Martín Fierro. Informe de Brodie. El perseguidor, La oveja negra, Bogotá, 1987, p. 32 (V, 875-876, primera parte).

${ }^{21} \mathrm{El}$ concepto de "pueblo", al igual que el de "nación", se transformó fuertemente entre 1750 y 1850. Generalizando, se pasó de un sentido étnico a uno político. Por ejemplo, el discurso político de "pueblo", como destinatario de la felicidad pública y de los goces de la civilización, ya estaba presente entre los ilustrados neogranadinos (Peralta Jaime, Andrés, Los novatores: la cultura ilustrada y la prensa colonial en Nueva Granada (1750-1810), op. cit., pp. 127-133; Garrido, Margarita y Luz, Martha, "Pueblo - Colombia", en Javier Fernández Sebastián (Dir.), Diccionario politico y social del mundo iberoamericano, La era de las revoluciones, 1750-1850, Iberconceptos I, Fundación Carolina y otros, Madrid, 2009, pp. 1176-1179).

22 Lomné, Georges, "República - Colombia", op. cit., pp. 1306-1320.

${ }^{23}$ König, Hans-Joachim, "Nación - Colombia", op. cit., pp. 910-911.

${ }^{24}$ Se hace referencia al debate entre el modelo estatalista y el individualista, analizado por Raymond Carré de Malberg (Carré De Malberg, Raymond, Teoría General del Estado, Fondo de Cultura Económica, México, 1978, p. 877 y ss.), criticado por Guillaume Bacot (Bacot, Guillaume, Carré de Malberg et l'origine de la distinction entre souveraineté du peuple et souveraineté nationale, Editions du CNRS, Paris, 1985, pp. 21-28) y recuperado por Maurizio Fioravanti (Fioravanti, Maurizio, Los derechos fundamentales: apuntes de historia de las constituciones, Trotta, Madrid, 
Con respecto a la referencia a la República y a la patria, con ella se buscaba un gran impacto simbólico en momentos en que se requería una unidad política criolla y la adhesión de las otras castas, para legitimar las nuevas estructuras de poder. Pero no se seguirá la senda de estas dos palabras, pues de hacerlo el trabajo se alejaría de su intención original.

Entonces, ¿las referencias a un contrato social, a un pueblo, a una República y a una patria, en vez de la "nación", permiten clasificar las constituciones de la Primera República como propias del modelo individualista, incluso jacobina, a partir de una concepción propia de "soberanía popular"? ¿Será más bien del modelo estatalista bajo una visión de "soberanía nacional" lo que se camufla con la alusión al "pueblo"? Para responder esta pregunta se acudirá a las propias constituciones de la época.

Antes de nada, debe partirse de que no existe un modelo puro ni una constitución que no presente hibridaciones entre diferentes ideologías. Pero, a pesar de estas aclaraciones iniciales, una constitución echa mano más de un modelo que de otro, lo que mantiene vigente las dos preguntas hechas anteriormente.

Ahora bien, usando como ejemplo la Constitución de Antioquia de 1812, podrian encontrarse elementos propios del modelo individualista y del concepto jacobino de "soberanía popular" en ciertos apartados de dicha constitución 25, que bien se presentaron de manera similar en las demás de dicho período. A saber:

- La radicación de la soberanía popular en el pueblo. Título primero, sección segunda, artículo 19: "La soberanía reside originaria y esencialmente en el pueblo".

- La indicación de que los ciudadanos pueden participar directamente en los procesos legislativos. Artículo 24, sección segunda, título primero: "Todas las elecciones deben ser libres, y cada ciudadano tiene un derecho igual de concurrir mediata o inmediatamente a la formación de leyes y al nombramiento de los representantes y funcionarios públicos".

\footnotetext{
1998, pp. 35-49). No se puede confundir, sin más, las tesis de la soberanía popular (como mera sumatoria de la voluntad de los individuos) con las defendidas realmente por Rousseau, pues existen ciertos puntos de distanciamiento. Por ejemplo, Rousseau consideró que la soberanía es indivisible e inalienable, pues es un acto de la voluntad general que, al expresarse, es ley (Ver: Rousseau, Jean Jacques, El contrato social, Porrúa, México, 1998, Libro $2^{\circ}$, cap. $2^{\circ}$ ). Generalizando, los defensores de la soberanía popular consideraron que ésta no nace de la voluntad general expresada por una mayoria (siguiendo el ejemplo de Rousseau: que la voluntad general no es unanimidad sino mayoria, pero dejando constancia de los votos contrarios) sino que la voluntad general es una receptora de la soberanía de los ciudadanos quienes luego de expresarse la delegan, por lo cual ella es divisible en su principio pero se manifiesta como unidad en su destino (para ello se fundan, paradójicamente, en el Libro $3^{\circ}$, Capítulo $1^{\circ}$ del "Contrato Social”). Se agradece al profesor Fernández Sarasola sus sugerencias para la redacción de esta nota.

25 Aspectos, en su mayoría, enunciados por: Estrada Vélez, Sergio Iván, "La importancia de la historia constitucional para la comprensión del constitucionalismo contemporáneo", en Estrada Vélez, Sergio Iván, "La importancia de la historia constitucional para la comprensión del constitucionalismo contemporáneo", en Andrés Botero (edit.), Origen del constitucionalismo colombiano. Ponencias del III Seminario Internacional de Teoria General del Derecho, Universidad de Medellín, Medellín, 2006, pp. 197-214.
} 
- El reconocimiento de los derechos del hombre y del ciudadano como fundamento necesario de la República. Artículo 2, sección primera, preliminares: "Considerando que el olvido de los sagrados e imprescriptibles derechos del hombre y de las obligaciones del ciudadano es la causa primaria y el origen del despotismo, de la tiranía y de la corrupción de los gobiernos, y que por este mismo olvido e ignorancia los pueblos sufren por muchos siglos la esclavitud y las cadenas, o cometen mil excesos contrarios al orden y a la institución de la sociedades".

- La afirmación de cuatro derechos señalados como principales y superiores (al ser sagrados) al propio Estado. Sección primera, preliminares: "Los representantes de la Provincia de Antioquia en el Nuevo Reino de Granada, plenamente autorizados por el pueblo, para darle una Constitución que garantice a todos los ciudadanos su Libertad, Igualdad, Seguridad y Propiedad"26.

- Por el principio de eficacia directa de la constitución que podría encontrarse en cuatro de sus artículos: a. Título X, artículo 1, Disposiciones generales ("Todo empleado y agente público de la provincia antes de entrar a ejercer las funciones de su empleo o para seguir en el ejercicio de las que obtenga en la actualidad, prestará el siguiente juramento: "Juro obediencia y fidelidad al Estado de Antioquia, observar y hacer observar su Constitución, cumplir fielmente las obligaciones que me incumben como (aquí el nombre del empleo), según mis talentos e inteligencia"). b. Título IV, Del Poder ejecutivo, artículo 11 ("Si en la ejecución de la ley hallare graves inconvenientes, ya sea por no haberse observado las formas de la Constitución, ya por contrariar a ésta, ya en fin por cualesquiera otros motivos, el Presidente tendrá derecho de objetar y devolver la ley a la Cámara que la propuso: así pondrá al pie el Decreto siguiente: "Objétese y devuélvase". En el oficio de devolución expresará las objeciones que le han ocurrido para no sancionar y dar cumplimiento a la ley"). c. Título IV, Del Poder ejecutivo, artículo 31 ("El Presidente deberá velar en la observancia de la Constitución y de las leyes: así estará a la mira de las operaciones de todos los jueces, tribunales y empleados públicos para que cada uno llene las obligaciones de su destino. En el caso de infracción notoria denunciará los miembros de los tres poderes a la Cámara de los Representantes, para que haga la debida acusación ante el Senado; y a los demás funcionarios a sus respectivos jueces para el castigo y reforma correspondientes, pues el Presidente por ningún motivo se mezclará en las atribuciones del Poder Judicial"). d. Título X, artículo 16, Disposiciones generales ("Todos y cada uno de los poderes, jueces y autoridades de la república observarán inviolablemente las leyes, ordenanzas, cédulas y reales órdenes que constituyen los códigos nacionales en todo aquello que no se hallen expresamente derogadas, o sea contrarias a la Constitución del Estado. En caso de duda consultarán al Poder Legislativo").

26 Estos derechos son la base del constitucionalismo provincial neogranadino. Por ejemplo, se encuentran en la Constitución de la República de Cundinamarca de 1812, específicamente en el artículo 1 del De los Derechos del Hombre, y sus Deberes: "Los Derechos del Hombre en sociedad son la igualdad, la seguridad, y la propiedad". 
- La contemplación de la revocatoria del mandato. Título I, sección segunda, artículo 25: "Para impedir a aquellos que están revestidos de la autoridad el que vengan a ser opresores, el pueblo tiene derecho en los períodos y en la forma que establezca por su Constitución de hacer que los empleados públicos vuelvan a la vida privada, y de llenar las vacantes, por elecciones ciertas y regulares".

- La institucionalización de la figura del "pacificador" o del conciliador, lo que supondría una participación ciudadana en el ejercicio de la función jurisdiccional: Título V, del poder judicial, sección tercera, artículo 9: "Ningún juez en calidad de tal llevará costas procesales, ni admitirá demanda por escrito, sin que haya precedido sobre ella un juicio verbal; al efecto nombrará tres vecinos y haciéndolo saber al actor y reo, tanto éste como aquel borraran uno de la lista, para que el tercero sea quien los oiga verbalmente, ejerciendo en esto las funciones de un pacificador".

No obstante, bien podria afirmarse a favor de la presencia de una cosmovisión propia de un estatalismo así como de una "soberanía nacional" en la Constitución antioqueña de 1812, a pesar del uso del concepto "pueblo", replicando los argumentos anteriores ${ }^{27}$, que:

- Al establecerse en el título primero, sección segunda, artículo 19 que la soberanía reside en el pueblo, inmediatamente se le cataloga como indivisible, por lo cual las manifestaciones individualistas que pregonan la divisibilidad de la soberanía quedan desechadas. Título primero, sección segunda, artículo 19: "La soberanía reside originaria y esencialmente en el pueblo. Es una e indivisible, imprescriptible e inajenable"28. De allí, por demás, la distinción de la época entre "pueblo" (soberano) y "pueblos" (poblaciones) ${ }^{29}$.

- Al señalar que los ciudadanos pueden participar directamente en los procesos legislativos (artículo 24, sección segunda, título primero) no se refirió la Constitución a cualquier individuo, sino a muy pocos varones que la misma Constitución identificó como los ciudadanos en sentido estricto,

27 Debe agradecerse al prof. Ignacio Fernández Sarasola por sus contribuciones a los siguientes puntos.

28 La indivisibilidad del pueblo soberano puede verse también en la Constitución de Cundinamarca de 1812, en: De los Derechos del Hombre, y sus Deberes, Art. 10 "La Soberanía residiendo en la universalidad de los Ciudadanos es una, indivisible, e inajenable"; Art. 11 "Ninguna porción, o parcialidad de Pueblo puede atribuirse Soberania"; Art. 12 "Si algún individuo se quisiese atribuir Soberanía, sería un tirano, y se le trataría como a tal". A su vez, se encuentra en la Constitución de la República de Tunja de 1811, especialmente en el Capitulo I, Artículo 18: "La soberanía reside originaria y esencialmente en el Pueblo; es una, indivisible, imprescriptible, é inajenable", Artículo 19: "La universidad de los Ciudadanos constituye el Pueblo Soberano" y Artículo 20: "La soberanía consiste en la facultad de dictar leyes, en la de hacerlas ejecutar, y aplicarlas a los casos particulares que ocurran a los ciudadanos, o en los Poderes Legislativo, Executivo, y Judicial". También puede evidenciarse en la Constitución de Mariquita de 1815, exactamente, en el Título Primero, Artículo 34: "La Soberanía reside en el Pueblo, es una, e indivisible, imprescriptible, inalienable".

29 Sá e Melo Ferreira, Fátima, "Entre viejos y nuevos sentidos: "pueblo" y "pueblos" en el mundo iberoamericano entre 1750 y 1850”, op. cit., pp. 1127-1135. 
que hace perder peso a un argumento individualista (a menos que el concepto de "individuo soberano" en el modelo individualista se restrinja a ciertos sujetos, siendo los demás no-individuos) ${ }^{30}$. Se agrega que esta consideración del "pueblo", pero reducido a unos ciudadanos-propietarios en lo que atañe a los derechos políticos y ampliado a toda la población en lo que compete a los deberes, deja en claro el maridaje entre modernidad y tradición, entre liberalismo y pragmatismo, que caracterizó dicho período ${ }^{31}$. $\mathrm{Y}$, adicionalmente, la identificación de derechos $\mathrm{y}$ deberes de los ciudadanos en la actividad legislativa, es algo que no es ajeno a la soberanía nacional.

- En la contemplación de la revocatoria del mandato (título I, sección segunda, artículo 25), se señala que es el "pueblo" (que es indivisible y que sólo opera mediante la acción de ciertos varones escogidos por la propia Constitución) el que puede destituir a un servidor público.

- El reconocimiento de los derechos del hombre y del ciudadano como fundamento necesario de la República, al interpretarse conforme a otros postulados constitucionales, como aquel que restringe al "Estado" y a la "ley" (artículo 6, sección primera, título tercero) la disponibilidad y el ejercicio de los derechos, presupone de algún modo que los rastros del modelo individualista en la Constitución van cediendo también a favor del estatalismo, y que, además de un individuo soberano propietario de unos derechos naturales previos al contrato social, también se concibe alli a un individuo subordinado y surgido del querer del Estado, este último responsable de la construcción posterior de la sociedad y de los derechos. En consecuencia, no es exacto del todo afirmar que esta Constitución se adscribe al modelo individualista de soberanía popular, por la remisión que hace la propia Constitución antioqueña a la voluntad general expresada en la ley del Estado como medio sine qua non para el ejercicio de los derechos, entre otras razones. Además, el artículo 6, sección primera del título tercero, por dar otro caso, se refiere al principio de generalidad de la ley, que también es aplicable a ambos modelos soberanos.

Incluso, observando el núcleo duro de la tesis del contrato social, se tiene que alli también se esconde un fuerte germen estatalista, en la medida que tras el contrato social, surgen al mismo tiempo el Estado y la sociedad, de modo que los individuos renuncian en abstracto a disponer libremente de sus derechos, sometiéndose a la voluntad general expresada mediante la

30 Evidenciable, por demás, en el Título IIII de la Constitución de la República de Cundinamarca de 1812. En este caso, queda claro que sólo pueden participar en procesos legislativos quienes sepan leer y escribir, condición que muy pocos tenían para la época. Artículo 18: "También los Ciudadanos que tengan observaciones con que contribuir, o reparos que objetar al proyecto de ley podrán hacerlo por escrito y serán admitidas, y tenidas en consideración, siempre que sean concisas, oportunos, y que guarden la moderación, decoro, y respeto correspondiente á la importancia del asunto, y á la dignidad del Cuerpo Legislativo".

31 Sá e Melo Ferreira, Fátima, "Entre viejos y nuevos sentidos: "pueblo" y "pueblos" en el mundo iberoamericano entre 1750 y 1850”, op. cit., pp. 1130-1132. Para el caso gaditano: Portillo Valdés, José María. "Cuerpo de nación, pueblo soberano. La representación politica en la crisis de la monarquía hispana”, op. cit., pp. 73-76. En lo que atañe a la ciudadania: Blanco, Jacqueline, “La revolución de los colores y la limitación de los derechos politicos a los colombianos durante la temprana república", Revista Prolegómenos Derechos y Valores, vol. 20, n. 40, 2017, pp. 77-95. 
ley. Entonces, desde la ficción usada para legitimar el nuevo estado de cosas, no hay pues un contrato o pacto social del individuo con el Estado (que sería, asimismo, efecto del mismo contrato), sino de los individuos entre sí, sometiéndose a la voluntad general (ley) que actualizará la renuncia que en abstracto han realizado los sujetos. Pero, en la práctica, el "pacto social" fue entre ciertos criollos que se instauraron como constituyentes, mientras que para las castas se presentó como un "pacto de subordinación" bien camuflado bajo el concepto de "pueblo"32.

- La afirmación de cuatro derechos señalados como principales (la libertad, la igualdad legal, seguridad y propiedad), no presupone necesariamente una visión de la soberanía popular, pues una Constitución de democracia representativa-nacional bien puede tener como ejes de la actividad del Estado (no constituido por un contrato social sino por un pacto de subordinación) dichos principios. Incluso, si la propia Constitución señala que el ejercicio de esos derechos depende de la voluntad del Estado, expresada mediante la ley, como efectivamente sucedió, se está más frente a un modelo estatalista-nacionalista que individualista-popular.

- El principio de eficacia directa de la Constitución y la figura de los "pacificadores" no son patrimonio de las constituciones adscritas al modelo de soberanía popular. Así, el artículo 1 del título X (sobre el juramento) y sobre todo el artículo 11 del título IV (que establece simplemente un veto, por más que éste pueda ejercerse por infracción constitucional) no traducen necesariamente el principio de eficacia directa de la Constitución, sino mecanismos comunes en constituciones de diversos orígenes. Lo realmente determinante para poder hablar del principio de eficacia directa de la Constitución no es tanto un juramento para su aplicación o un poder de veto, sino que la Constitución sea directamente aplicable por los poderes públicos, sin mediación legal, y muy en especial por los jueces, para la resolución de conflictos particulares, donde se la juegan hoy dia la supremacía y la rigidez constitucional ${ }^{33}$. Tampoco son sintomáticas de la

${ }^{32}$ No se puede olvidar la diferencia jurídica entre contrato o pacto social, de un lado, y pacto de subordinación, del otro. Esto último dio lugar al pactismo, que caracterizó al Antiguo Régimen (García Pelayo, Manuel, Del mito y de la razón en el pensamiento político, Revista de Occidente, Madrid, 1968, pp. 97-140). Incluso, gracias a esta diferencia es posible clasificar, junto a otros elementos, las cartas de derechos y las constituciones mismas entre historicistas, individualistas y estatalistas. Cfr. Fioravanti, Maurizio, Los derechos fundamentales: apuntes de historia de las constituciones, op. cit., pp. 25-53.

33 En la doctrina jurídica contemporánea se diferencia la "supremacía constitucional" de la "rigidez de la constitución". La primera se refiere a la jerarquía formal de la constitución frente a la ley. La segunda se refiere al procedimiento agravado de reforma en comparación con la ley. A pesar del evidente anacronismo, en la Constitución antioqueña de 1812 existieron algunos instrumentos que podrían ser leídos como propios de una muy incipiente supremacía constitucional (Título X, artículo 1, Disposiciones generales; Título IV, Del Poder ejecutivo, artículo 11; Título IV, Del Poder ejecutivo, artículo 31; Título X, artículo 16, Disposiciones generales; ejemplos analizados anteriormente), pero estos instrumentos no han sido exclusivos de constituciones propias de la soberanía popular. Además, en la Constitución de 1812 existió un procedimiento de reforma constitucional más gravoso que el de una reforma legal (Título X, Disposiciones generales, artículo 17 y siguientes), lo que permitiría suponer, con alguna ligereza, de rigidez constitucional, asunto que tampoco ha sido exclusivo de las constituciones adscritas a una soberanía popular. 
soberanía popular las elecciones periódicas (título I, sección II, artículo 25). $\mathrm{Y}$ en cuanto a los "pacificadores", que suponen una participación ciudadana en el ejercicio de la función jurisdiccional, tampoco conducen necesariamente a la soberanía popular, pues bien puede interpretarse que dicho vecino pacificador representa a la "nación católica".

- Es interesante partir de la distinción muy significativa en la teoría de la soberanía nacional, entre la titularidad y el ejercicio de la soberanía. De esta manera, enunciar al pueblo como titular de la soberanía no significa bajo la lógica de la soberanía nacional que él deba ejercerla. Entonces la fijación del pueblo como titular de la soberanía no implica de suyo una visión propia de la soberanía popular, si dicha Constitución establece paralelamente un sujeto de ejercicio de la soberanía en abstracto (el Estado) y en concreto (el ciudadano criollo, católico, propietario, mayor de edad, etc.). Súmese a estas consideraciones un asunto que constituye un eje del presente trabajo: la presencia en el constitucionalismo provincial de diversos elementos, incluso contradictorios; esto hace que cualquier interpretación que tienda a reducir dicho constitucionalismo a un solo elemento, invisibilizando los otros, debe ser denunciada. Por ejemplo: la Constitución antioqueña de 1812 señala, explícita e implícitamente, varios sujetos y ejercitadores de la soberanía: el pueblo católico, el individuo, el Estado, la provincia, etc. La presencia de varios soberanos pone en duda cualquier interpretación absolutista tanto de la soberanía nacional como de la popular, lo que no impide, claro está, sentar postura sobre si una concepción pesaba más que la otra en un contexto determinado.

Entonces, salvando lo dicho anteriormente, ¿a qué modelo de soberanía se inscribió más la Constitución antioqueña de 1812? Si bien hay elementos propios de una concepción de soberanía nacional así como de una popular, fruto de la tensión y la complejidad que están en el fondo del esquema constitucional provincial, en este trabajo el interés está centrado en poner en evidencia al "pueblo católico" como sujeto soberano por los efectos socio-políticos que propició no sólo en las dos primeras décadas del siglo XIX, sino incluso hasta días más recientes ${ }^{34}$. Pero volviendo a la pregunta, esta concepción de "pueblo" está más de la mano de una soberanía nacional que de una individualista, popular o jacobina, esto si se hace una interpretación sistemática tanto de la mismas constituciones provinciales como de la propia realidad política que la circundaba. De esta forma, atendiendo al significado y las relaciones sistemáticas, el soberano pueblo no difirió en mucho (aunque obviamente hubo matices diferenciadores) de lo que en otras latitudes llamaron, sin pudor, soberano-nación.

En consecuencia, "pueblo" y "patria" vinieron a ser interpretados como una unidad de voluntad política que, escapando a una fragmentación individual, permitiría, según estas constituciones, el paso de un derecho colonial a uno de carácter estatal y, con éste, a uno nacional (pues en estas tierras, como ya se dijo, el Estado sería el responsable de crear la nación política). Esto queda claro si se tiene en cuenta que, durante la Primera República, tanto desde la normativa

34 En especial por su ascendencia en la conformación del formalismo jurídico colombiano, analizado en: García Villegas, Mauricio, "Apuntes sobre codificación y costumbre en la historia del derecho colombiano", Revista Opinión Jurídica, n 8, 2005, pp. 53-71. 
constitucional como desde las prácticas políticas, sólo unos pocos tuvieron pleno acceso a las libertades de participación ${ }^{35}$; que no estaba del todo establecido un uso moderno del término "ciudadano" 36 ; que los partidos eran vistos de manera peyorativa como desmembradores de la unidad; que las proclamas y los discursos reiteraban la unión en torno a una sola estructura política liderada por los criollos en juntas o colegios; que el estatalismo debía ser el garante de la unidad de voluntad nacional; que la "única religión verdadera" debía moldear la única depositaria de la soberania; que los derechos individuales no pasaron de ser consagraciones programáticas y pragmáticas sin sistemas de garantía, etc.

De este modo, si las constituciones provinciales hubiesen sido eficaces, el estatalismo, con los matices ya vistos, habría sido la consecuencia directa del discurso del pueblo-católico, porque la "soberanía del pueblo" vendría siendo la del aparato estatal; se buscaba así pasar de una "monarquía católica" a la de un "pueblo-católico" (en el constitucionalismo provincial neogranadino) ${ }^{37}$ o a la de una "nación-católica" (en el constitucionalismo gaditano) ${ }^{38}$, los cuales deberían ser interpretados en clave "Estado" (todo dentro de una lógica de "nacionalización de la religión"39). Sería la voluntad (expresada dentro del Estado) y no el vínculo natural el elemento de cohesión nacional. Como dice Nicolás Tenzer: "cuando en 1789 se proclamó que la soberanía reside en la nación, se manifestó negativamente en quién había dejado de residir (el rey y su sucesión dinástica)"40, pasando así de la "monarquía católica" al "pueblo católico" o a la "nación católica", según el caso. "A la vez, no se podía depositar directamente esa soberanía en el Estado sin un proceso previo de "despersonalización" del mando político, hasta ese entonces encarnado en el monarca. La nación era soberana y ella depositaba, legitimándolo así, la soberanía en el Estado"41, con lo cual éste produciria leyes sabias y justas ${ }^{42}$ (muy ligado al formalismo ético que surgió en la Europa del XIX, que identificaba como moralmente bueno todo aquello que la ley ordenaba). "Así podía mantenerse un desdoblamiento (Nación legitimante, Estado legitimado) y hasta una triplicación: (i) Patria del sentimiento, manifestada en la (ii) voluntad de la Nación, expresada en la persona jurídica del (iii) Estado

35 El ciudadano es un sujeto identificado por la nación, según lineamientos de sexo, credo, propiedad, etc. Portillo Valdés, José Maria, Revolución de nación: orígenes de la cultura constitucional en España, 1780-1812, Centro de estudios politicos y constitucionales, Madrid, 2000, p. 18.

36 König, Hans-Joachim, "Ciudadano - Colombia", en Javier Fernández Sebastián (Dir.), Diccionario político y social del mundo iberoamericano, La era de las revoluciones, 1750-1850, Iberconceptos I, Fundación Carolina y otros, Madrid, 2009, pp. 234-246.

37 Velásquez, Érika, “La religión católica en las constituciones neogranadinas de 1811 a 1815”, Revista Facultad de Derecho y Ciencias Políticas, vol. 36, n 105, 2006, pp. 283-298.

38 Portillo Valdés, José María, Revolución de nación: orígenes de la cultura constitucional en España, 1780-1812, op. cit., pp. 21-22. Portillo Valdés, José María, "Cuerpo de nación, pueblo soberano. La representación politica en la crisis de la monarquía hispana”, op. cit., pp. 47-76.

39 A la que alude, entre otros, Gramsci Antonio, La formación de los intelectuales, Grijalbo, México, 1967, p. 155.

40 Bandieri, Luis María, Patria, Nación, Estado et quibusdam aliis, op. cit., p. 26.

41 Bandieri, Luis María, Patria, Nación, Estado et quibusdam aliis, op. cit., p. 26.

42 Portillo Valdés, José María, Revolución de nación: orígenes de la cultura constitucional en España, 1780-1812, op. cit., p. 16. 
soberano"43. El Estado pensado en las constituciones de la Primera República, partió de los conceptos de "pueblo", "patria" y "república", convirtiéndolos en abstracciones útiles para ser usados como credenciales de legitimación ${ }^{44}$.

El Estado, tal cual como fue ideado en el constitucionalismo provincial, tendría como misión consolidar el pueblo-nación que, supuestamente si se miran las propias constituciones, le había dado origen, cerrándose así el ciclo político y abstracto que ocultaba los reales juegos de poder que ocupaban y enfrentaban a las provincias entre sí, y dentro de ellas, a las ciudades y las familias criollas que las gobernaban. El Estado moderno, dentro de cada provincia, se establecería "sobre las patrias concretas de geografia variable y sobre los diversos agrupamientos étnicos que antes se denominaban 'naciones" 45 . El Estado lograría así articularse con el pueblo-nación, pues como lo dijo Simone Weil: "no es posible definir la palabra 'nación' sino como el conjunto de territorios que reconocen la autoridad del mismo Estado". Y agregó, refiriéndose a Francia pero igualmente aplicable, mutatis mutandis, al caso hispanoamericano, "la operación por la cual la Revolución sustituyó al rey por la soberanía nacional no tenía más que un solo inconveniente, y es que la soberanía nacional no existía"46. El pueblo-nación y la soberanía nacional "son abstracciones que velan la imposición del aparato estatal bajo una nueva unción legitimadora"47: la religión (explicándose así, por ejemplo, la continuidad de la política de protección estatal a la Iglesia durante el constitucionalismo provincial e incluso durante buena parte del XIX).

De esta manera, al convertirse la nación en sinónimo de libertad y emancipación, tanto en Francia como en Cádiz, sumado a la fuerza que el término tomaba entre los filósofos más destacados, verbigracia ejemplo Montesquieu (al describir un "espíritu de las naciones" a partir de variables geográficas en comunicación con sus leyes ${ }^{48}$ ), Rousseau (fundada en la bondad originaria del hombre y en la voluntad general como metafisica creadora del Estado y del derecho) y Hegel (quien asemeja el Volksgeist ${ }^{49}$ a un individuo que marcha en la historia de la Humanidad, con objetivos a realizar), los países hispanoamericanos, en este período que ahora se estudia, pretendieron erigirse igualmente como pueblos-naciones, para alcanzar de una vez por todas la "mayoria de edad".

43 Bandieri, Luis Maria, Patria, Nación, Estado et quibusdam aliis, op. cit., p. 26.

44 Bandieri, Luis Maria, Patria, Nación, Estado et quibusdam aliis, op. cit., p. 26.

45 Bandieri, Luis Maria, Patria, Nación, Estado et quibusdam aliis, op. cit., p. 23.

46 Weil Simone, Raíces del existir -preludio a una declaración de deberes hacia el ser humano (1943), Sudamericana, Buenos Aires, 1954, p. 108. Citado por: Bandieri, Luis María, Patria, Nación, Estado et quibusdam aliis, op. cit., p. 23.

47 Bandieri, Luis Maria, Patria, Nación, Estado et quibusdam aliis, op. cit., p. 23.

48 Montesquieu, Del espíritu de las leyes, Altaza, España, 1993, Libro IX.

49 Hegel, Jorge Guillermo Federico, Lecciones Sobre la Filosofía de la Historia Universal (1830), Revista de Occidente, Madrid, 1952, pp. 47-48. "Espíritu del pueblo", literalmente, que el filósofo alemán utiliza indistintamente con Nationalgeist. 
"Se levanta a la faz de la tierra/ Una nueva y gloriosa nación" decía el texto originario del Himno Nacional Argentino, escrito en 1813 por Vicente López y Planes. Pero dicha alusión no era más que un proyecto desde el Estado, por lo que argüir la existencia de la nación desde el momento de erigirse las constituciones de Independencia habría sido algo atrevido, aunque no por ello dejaron de referirse a ella como "pueblo católico" o como programa politico, social y religioso de los criollos, plasmado en constituciones, las cuales eran más o menos desconocidas en sus detalles más importantes por parte de las castas.

Así las cosas, hasta el momento puede concluirse que la alusión constitucional al pueblo católico no implicó, en absoluto, un rechazo a la concepción nacionalista y antijacobina.

\section{LA CONVENIENCIA DE LA ALUSIÓN AL PUEBLO EN VEZ DE LA NACIÓN}

Pero si el concepto de "pueblo", en el contexto constitucional y político, no implicó una distinción significativa fuerte con el de "nación", entonces ¿qué pudo explicar el que se haya preferido aquél en vez de este?

En primer lugar, se explica la escasa alusión al concepto de nación por parte de los criollos en juntas, por la remisión que ello habría implicado necesariamente al discurso de la Junta Central, la Regencia y las Cortes, quienes hablaron en pro de una nación española de ambos hemisferios. Señaló la Constitución gaditana en su artículo 3: "La soberanía reside esencialmente en la Nación, y por lo mismo pertenece a esta exclusivamente el derecho de establecer sus leyes fundamentales".

Entre las provincias rebeldes, se consideró que esa "nación" estaba a un paso de extinguirse en la Peninsula ante la fuerza arrolladora de los franceses. Sin embargo, la alusión a la "nación" fue asumida como propia por las provincias y las ciudades que se mantuvieron leales a la Corona, las cuales lideraron la respuesta militar ante la Independencia50. Por tanto, la "nación" pasó a ser el criterio enemigo del proceso emancipador pues representaba a la España monárquica, pero no a la Nueva Granada rebelde.

Se agrega que fue común en las proclamas y actas de independencia dentro de las provincias rebeldes, una retórica estratégica para pasar de una "nación" a un "pueblo", como el soberano. Sintetizando, se partió de que la soberanía de la nación le correspondía al rey, pero al ser apresado por Napoleón la soberanía nacional recayó en los "pueblos" quienes debían constituir una regencia según los usos y las costumbres del reino mientras se lograba el retorno del rey (por eso fue llamado "el Deseado"); pero -dado que los criollos consideraron que no se respetaron esos usos y costumbres, de un lado, y que la "nación" estaba perdida ante Napoleón, del otro- cada "pueblo" provincial debería reasumir la soberanía, otrora de la "nación", y entregársela mayormente a los cabildos51, quienes

50 Entre 1811-1814, en la Nueva Granada, se libró no sólo una disputa militar y política entre centralistas y federalistas; también entre provincias leales a las Cortes de Cádiz y las rebeldes. Botero, Andrés, "Una sombra en la noche: en torno al constitucionalismo gaditano y la Nueva Granada", Historia Constitucional, n 15, 2014, pp. 311-389.

51 Por dar un caso, se transcribe un apartado del "Acta de formación de la Junta de la villa del Socorro", del 11 de julio de 1810: "Restituido el pueblo del Socorro a los derechos sagrados e imprescriptibles del hombre por la serie de sucesos referida, ha depositado provisionalmente el 
deberian reunirse entre sí, conformándose en juntas o colegios, primeramente para darse un gobierno mientras regresaba el rey legítimo (creyendo la mayoría que eso sería imposible) ${ }^{52}$, luego para darse la independencia ${ }^{53} \mathrm{y}$, finalmente, darse constitución. Así, de la "nación española”, surgiría el "pueblo provincial" soberano constituyente.

En segundo lugar, por la ausencia de una cultura común, de un lado, y por asuntos domésticos, del otro. Con ocasión de la invasión francesa a la Península, la defensa de la "nación" se asumió allí como el discurso jurídico-político legitimante de la guerra contra los Bonaparte ${ }^{54}$. Esto se vio alimentado por elementos culturales que permitieron a los que combatían contra los soldados de

gobierno en el muy ilustre Cabildo... Pero hallándonos unidos por estrechos vínculos de fraternidad con los ilustres cabildos de las muy nobles y leales ciudad de Vélez y villa de San Gil, y siendo comunes nuestros intereses por la respectiva situación geográfica, determinó el cabildo que se comunique esa acta a dichos ilustres cabildos, convidándolos a que manden dos diputados para deliberar sobre el plan y modo de gobierno que debemos establecer". Transcrito en: Quintero, Inés y Martínez, Armando, Actas de formación de juntas y declaraciones de independencia (18091822), op. cit., p. 302.

52 Señala el "Acta constitucional de la Junta provincial del Socorro" del 15 de agosto de 1810: "No habiendo reconocido el Cabildo del Socorro al Consejo de Regencia hallándose ausente su legitimo Soberano el señor don Fernando Séptimo, y no habiéndose formado todavía Congreso Nacional compuesto de igual número de Vocales de cada Provincia para que reconozca y delibere sobre los grandes intereses del cuerpo social, y los de paz y guerra, reasume por ahora todos esos derechos. Cuando se haya restituido a su trono el Soberano, o cuando se haya formado el Congreso Nacional, entonces este pueblo depositará en aquel Cuerpo la parte de derechos que puede sacrificar sin perjuicio de la libertad que tiene para gobernarse dentro de los limites de su territorio, sin la intervención de otro Gobierno. Esta Provincia organizando así el suyo será respecto de los demás como su hermano siempre pronto a concurrir por su parte a la defensa de los intereses comunes a la familia”. Quintero, Inés y Martínez, Armando, Actas de formación de juntas y declaraciones de independencia (1809-1822), op. cit., p. 307.

53 Verbigracia la "Declaración de independencia de Cundinamarca", del 16 de julio de 1813: "Nos, los representantes del pueblo de Cundinamarca, legítima y legalmente congregados para tratar y resolver lo concerniente a su felicidad, habiendo tomado en consideración el importante punto de si era ya llegado el caso de proclamar solemnemente nuestra absoluta y entera independencia de la corona de España, por la emancipación en que naturalmente hemos quedado después de los acontecimientos y disolución de la Península y gobierno de que dependíamos, habiendo tenido largas y maduras discusiones en que se trajeron a colación las antiguas obligaciones que por solemnes juramentos nos unian a la madre patria, los que nuevamente se habian hecho, el espacio de tres años en que nos hemos mantenido en un estado de expectación y de neutralidad respecto a los sucesos de la España Europea; y finalmente la necesidad en que nos ponía a deliberar y tomar un partido activo la aproximación de tropas mandadas por el Gobierno de España y a nombre de un rey que en el dilatado tiempo de cinco años no se sabe haya hecho el menor esfuerzo para salvar la España de los males que la abruman, y mucho menos para librar la América de correr igual suerte, hemos decretado (...) En consecuencia de todo esto, y en atención, finalmente, al derecho incontestable e imprescriptible que tienen todos los pueblos de la tierra de proveer a su seguridad y de darse la forma de gobierno que crean más conveniente a labrar su felicidad; nosotros los representantes del pueblo de Cundinamarca, usando de este derecho y compelidos a adelantar este paso por los esfuerzos de nuestros impolíticos y crueles opresores, declaramos y publicamos solemnemente, en nombre del pueblo, en presencia del supremo Ser, y bajo los auspicios de la Inmaculada Concepción de María Santísima, patrona nuestra, que de hoy en adelante, Cundinamarca es un estado libre e independiente". Quintero, Inés y Martínez, Armando, Actas de formación de juntas y declaraciones de independencia (1809-1822), op. cit., pp. 283-287.

54 Wasserman, Fabio, "el concepto de nación y las transformaciones del orden politico en Iberoamérica, 1750-1850”, op. cit., p. 859. 
Napoleón, sentirse diferentes culturalmente (por idioma, origen, costumbres, etc.) de los franceses. Por tanto, la cultura también permitió diferenciar las naciones en guerra: España y Francia. Pero en la Nueva Granada, a pesar de que merodeaba un discurso de identidad americanista55, la "nación" no logró travestirse de cultura, en tanto no habia unidad cultural en la Nueva Granada, pues cada casta tenía sus propias identidades, y entre los criollos revolucionarios no habia un elemento cultural que los diferenciase fuertemente de los criollos regalistas ni de los españoles peninsulares ${ }^{56}$. ¿Cómo alegar una "nación" que reclama su independencia, cuando el enemigo no tenía una distinción cultural tan marcada que permitiese su exclusión bajo dicho concepto politico?

Además, las urgencias domésticas fueron un obstáculo para aludir, durante la Primera República, a la nación como soberana. Como se sabe, durante la Primera República, se produjo una fuerte tensión, que no se resolvió plenamente, ni siquiera por la vía militar, entre los defensores de un modelo provincial-federal con los de un sistema centralista al momento de constituirse las Provincias Unidas de la Nueva Granada. Dentro de esta tensión es que puede comprenderse la eficacia simbólica del uso del concepto de "pueblo católico" como una manera de oponerse a la construcción de un poder político central fuerte y, con él, a la posible adscripción a una identidad nacional: la Nueva Granada.

Resulta pues que con la adscripción a una tesis de soberanía popular, los intereses domésticos, tal como lo señaló Rousseau en sus ejemplos cantonales, serian la piedra fundamental sobre la cual debería construirse el Estado fruto del pacto social. Ante esta situación práctica y teórica, se observa en las preliminares de la Constitución de Antioquia de 1812 la consagración de que la soberanía, una vez devuelta al "pueblo católico", se reasignaría nuevamente en la conformación de un "gobierno sabio, liberal y doméstico". Alli se hace referencia inicialmente a un gobierno sabio, que se expresaría en el ideal constitucional provincial de crear un Estado racional a la vez que religioso, en tanto se funda en tesis iusnaturalistas racionalistas y teológicas (pues los cuatro derechos sagrados son producto, a su vez, de una razón universal que, según los hispanoamericanos, los ilustrados franceses no supieron articular, descartando en su fundamento el planteamiento católico subyacente ${ }^{57}$ ), y que con el paso del tiempo sirvieron de puente a la formación del estatalismo en su particular forma latinoamericana. Este Estado, al ser efecto político del "pueblo" soberano, se manifestaría a los

55 Feres Junior, João, “El concepto de América: ¿concepto básico o contraconcepto?”, op. cit., pp. 51-67. Wasserman, Fabio, El concepto de nación y las transformaciones del orden politico en Iberoamérica, 1750-1850”, op. cit., pp. 861-863.

56 König, Hans-Joachim, "Nación-Colombia”, op. cit., p. 912.

57 "El fundamento de los derechos del hombre no estaba en el hombre mismo, sino en un orden superior a él. Si propiedad, seguridad, libertad y resistencia a la opresión eran derechos del hombre, lo eran por un mandato divino" Portillo Valdés, José María, Revolución de nación: origenes de la cultura constitucional en España, 1780-1812, op. cit., p. 139.

Se agrega que estos cuatro derechos, puestos como superiores por las Constituciones provinciales neogranadinas, demuestran -una vez más- la influencia que sobre el constitucionalismo hispanoamericano tuvieron las ilustraciones, los liberalismos y las revoluciones estadounidense, francesa y haitiana, puesto que dicha jerarquía de los derechos era comúnmente aceptada en los procesos acabados de mencionar. 
hombres por medio de actos de voluntad general, igualmente racionales, como lo es la ley, a la cual debería obedecerse religiosamente.

Se menciona allí, además, la existencia de un gobierno liberal, pues aplicaría los principios del liberalismo político (Estado, principio de legalidad, división de poderes, etc.) y auspiciaría unos derechos individuales pero sujetados a la voluntad (ley) estatal. El liberalismo, entendido en una forma moderada como era de esperarse en aquellos momentos, se potenció en tanto conectado a una tradición considerada como la verdadera: el catolicismo. De otra manera, un liberalismo ateo o agnóstico seguramente no habría dejado ninguna estela.

Y ese gobierno, por demás, sería doméstico, pues nadie más preocupado por el futuro de la región que los propietarios que allí tenían sus tierras. Creían los constituyentes que el poseer una tierra, cuya relación con el dueño es más que un simple activo en dichos momentos precapitalistas, garantizaría la racionalidad del ejercicio político concedido generosamente por el "pueblo católico" y evitaría cambios peligrosos para las estructuras económicas dominantes. Por lo anterior, se planteó un ejercicio de control a las pretensiones hegemónicas de Santa Fe de Bogotá (la principal interesada en aludir a una nación en vez de pueblos provinciales) y al miedo que esta ciudad capital siempre suscitó ante muchas juntas independentistas del momento. Santa Fe no permitiría el gobierno doméstico de los propietarios locales por encima de los intereses nacionales.

Así, el "pueblo católico" fue una expresión soberana doméstica, que legitimó en buena medida la politica federalista, pero fue desechada rápidamente en el segundo proceso constitucional neogranadino, esto es, en la Segunda República.

Por todo esto los criollos constituyentes no pudieron hablar tranquilamente de "nación" en sus documentos jurídicos. Ya se dijo que hacer referencia a la nación podría implicar un acercamiento nada conveniente a la "nación española", la cual se creyó moribunda, que se enfrentaba en la Península a los franceses y en América a las juntas revolucionarias de la Primera República; pero también podría significar, en el sentido medieval, aludir a una unidad étnica y cultural, la cual no se tenía en ese mismo sentido en América y que sería contraproducente pues los criollos buscaban, por convicción ideológica (el liberalismo político) o pragmatismo político (el miedo a un guerra entre castas que significase el fin del predominio criollo ${ }^{58}$ ), el respaldo de las castas, lo que hizo que, por lo menos en el papel, fuesen tratados como iguales ante la ley salvo en lo que atañe a los derechos politicos.

Se concluye que el uso del concepto de pueblo, a pesar de su marcado acento nacionalista, fue estratégico: un contrapeso semántico al uso constante de la palabra "nación" por parte del enemigo: el Imperio.

58 Botero, Andrés, Modelo de lectura del constitucionalismo provincial hispanoamericano: origen del constitucionalismo antioqueño, op. cit., pp. 23-32. Blanco, Jacqueline, “La revolución de los colores y la limitación de los derechos políticos a los colombianos durante la temprana república", op. cit., pp. 77-95. 


\section{APARICIÓN DE LA NACIÓN COMO SOBERANO}

Resulta que el discurso nacionalista recobró alguna importancia constitucional, como ya se mencionó, cuando se conformaron las Provincias Unidas de la Nueva Granada (1811-1816), organismo que intentó fomentar, en el poco tiempo de vida que tuvo, un sentimiento nacionalista, en vez de uno popular que ya estaba bien enraizado en las provincias, para legitimarse politica y jurídicamente 59 . Sin embargo, fue mayor la importancia que tomó el concepto de nación gracias a la ideologia militar de la guerra de Independencia en su segunda fase. En este sentido, hay que diferenciar dos momentos bélicos de la Independencia. En primer lugar, la guerra durante la Primera República, como era de esperar, se rigió bajo los parámetros propios de la guerra premoderna, esto es, con la ideología militar propio del Antiguo Régimen, que bien puede denominarse como "guerra cívica", la cual se caracterizó por ser limitada y local: "todo conspiraba para que el nivel de violencia fuera bajo y los conflictos interminables. La guerra se resumía en una especie de semiótica; no se buscaba aplastar al adversario sino convencerlo de que continuar la lucha era inútil"60. Incluso, este modelo de guerra tradicional era el que más acorde estaba con la evolución política y doméstica de los conflictos bélicos durante la Primera República, los cuales eran más entre ciudades, entre familias criollas, entre provincias leales y rebeldes, entre federalistas y centralistas, etc. Dicho con otras palabras, no había mayor ideal nacional, a lo sumo patriótico, en la ideología militar de aquel momento. Solo fue a partir de 1814 y 1815 , con una nueva fase en la guerra de Independencia, que empezó a perfilarse un cambio en la doctrina militar, dejando poco a poco el modelo tradicional para asumir la ideología bélica moderna, altamente influida por las guerras revolucionarias francesas y, más especialmente, por las napoleónicas, en las que se forjaron la mayoría de los combatientes regalistas liderados por Pablo Morillo61, guerras que dieron un

59 Verbigracia la "Declaración de Independencia de la provincia de Tunja" del 10 de diciembre de 1813: "El pueblo de la Provincia de Tunja de la Nueva Granada, en la América Meridional, por la voz de sus representantes reunidos en su capital, a los demás pueblos del continente y naciones del Mundo: (...) declara a la faz del Universo que no reconoce ninguna subordinación al Gobierno de la Península, bien sea el que ha establecido hoy con el nombre de Corte y Regencia, o cualquier otro que se establezca en la sucesión de los siglos; que sólo reconoce y obedece al Gobierno que ella misma se ha dado para su régimen interior, y al general del Congreso de las Provincias Unidas de la Nueva Granada en lo tocante a los intereses comunes y nacionales, bajo los principios establecidos en el acta de unión acordada en 27 de noviembre de 1811 por los representantes de las mismas Provincias". Transcrito en: Quintero, Inés y Martínez, Armando, Actas de formación de juntas y declaraciones de independencia (1809-1822), op. cit., p. 300.

60 Thibaud, Clément, "Formas de guerra y construcción de identidades politicas: la Guerra de Independencia (Venezuela y Nueva Granada 1810-1825)”, Análisis Político, n 45, 2002 , p. 38 (pp. 35-44).

61 Todo un héroe de la Guerra de Independencia española ante los Bonaparte. El plan de Morillo era retomar el virreinato de la Nueva Granada para luego pacificar Perú y Mar del Plata. Morillo, Pablo, Memorias (1826), Incunables, Bogotá, 1991. Existe una biografia de Morillo que deja en claro su extracción popular; su mediocre carrera militar como infante de marina (cuerpo al que se enrola en 1791); sus rápidos ascensos, gracias a la Guerra de Independencia española, hasta convertirse en héroe nacional, dios para sus tropas y hombre de confianza de los mandos ingleses que combatían en la Península contra Napoleón; su nombramiento como pacificador de América en 1814; su campaña militar -con grandes errores políticos- en Venezuela y la Nueva Granada a partir de 1815; y su regreso a España: Quintero Saravia, Gonzalo, Pablo Morillo: General de dos mundos, Planeta, Bogotá, 2005. 
estímulo importante para crear una identidad colectiva entre los pueblos en lucha. Entonces, los rebeldes bien aprendieron de sus enemigos la importancia de un cambio en la doctrina militar (que empezó a perfilarse con el decreto de guerra a muerte de Bolivar de 1813 pero que se consolidó con posterioridad), lo que propició una mutación radical en la concepción del poder soberano.

Con esta nueva forma de ver la guerra, "se busca aniquilar por completo el ejército enemigo y tomar su capital lo más pronto posible para destruir al gobierno hostil... se busca la batalla decisiva para acabar lo más rápidamente posible con él"62. De esta manera, los cambios en la ideología bélica, conllevaron al nacionalismo (como forma, entre otras cosas, de superar los conflictos locales y particulares entre las huestes independentistas); a la militarización de la vida civil (los militares pasan a ser el "pueblo" general, que supera las distancias de los "pueblos" particulares, para dar paso a la "nación"63); a la justificación católica de la guerra64; y a la consideración del "otro" como un enemigo que debía ser erradicado, "otro" que poco a poco dejaba de ser una localidad vecina, un clan familiar rival u otra provincia, para ser reemplazado por el "chapetón", el español. Así, resumiendo, se pasó de una guerra cívica premoderna, a una guerra nacional moderna, que decantó en una guerra patriótica radical, de vencer o morir, bajo la cual el ideario nacionalista pasó a ser fundamental.

Así, desde la doctrina militar y las nuevas formas de la guerra, se puede explicar el paso de un proceso de independencia y constitucionalismo local y provincial, con una soberanía anclada en el "pueblo", a uno centrado en la nación, todo a partir de la progresiva radicalidad que asumió el conflicto armado, el cual, a su vez, como si se tratase de una serpiente que devora su cola, se vio fortalecido por la ideología nacionalista. El escalonamiento del conflicto fue, entonces, causa y efecto del nacionalismo, como todo un círculo vicioso: "poner en marcha unas prácticas guerreras que expliquen y justifiquen la guerra" misma65.

A esto se debe sumar que los defensores de la causa monárquica ya no se enfrentaban a los rebeldes bajo la bandera gaditana, que afirmaba una soberanía nacional bihemisférica, pues las Cortes de Cádiz, junto a su Constitución, fueron proscritas en Valencia por Fernando VII en 1814, sino bajo la bandera monárquica-borbónica tal como la había impuesto la Restauración ${ }^{66}$. De esta forma, para los independentistas, al desaparecer la Constitución y las Cortes de Cádiz, quedó libre para su uso el concepto de nación sin que ello implicara una concesión indebida al enemigo. Fue en ese contexto, sumado al cambio de doctrina militar, que empezó un nuevo capítulo de la percepción que tuvo la

62 Thibaud, Clément, "Formas de guerra y construcción de identidades politicas: la Guerra de Independencia (Venezuela y Nueva Granada 1810-1825)”, op. cit., p. 38.

63 Garrido, Margarita y Luz, Martha, "Pueblo - Colombia”, op. cit., p. 1182. Sá e Melo Ferreira, Fátima, "Entre viejos y nuevos sentidos: "pueblo" $y$ "pueblos" en el mundo iberoamericano entre 1750 y 1850", op. cit., pp. 1134-1135.

64 Garrido, Margarita y Luz, Martha, "Pueblo-Colombia”, op. cit., p. 1182-1183.

65 Thibaud, Clément, "Formas de guerra y construcción de identidades politicas: la Guerra de Independencia (Venezuela y Nueva Granada 1810-1825)”, op. cit., p. 41.

66 Sobre la evolución del concepto de "nación" en España: Portillo Valdés, José María. "Nación España”, op. cit., pp. 919-928. 
Constitución gaditana de 1812 en la Nueva Granada67. Así, se pasó de la naciónespañola (bihemisférica) enfrentada a cada pueblo provincial, a la monarquía española (peninsular) enfrentada a la nación neogranadina.

Se agrega que el concepto de nación le debió mucho al fortalecimiento del componente mestizo en los ejércitos independentistas, quienes ascendieron rápidamente durante la guerra, especialmente en su segunda fase, y lograron, más adelante, imponer en la sociedad política el mismo parámetro verticalista propio de la milicia. Entonces, mientras durante la Primera República predominó constitucionalmente la opción por gobiernos colegiados, propios de la aristocracia, durante la Segunda se prefirió gobiernos personales, con mando vertical, para la construcción del Estado y de la nación 68 . Dice así Almario: "el mestizaje como corpus discursivo es una construcción social posterior a este período seminal de las identidades, pero con el tiempo devino en componente fundamental de la invención de la nación en estas latitudes, en una manera de exorcizar el pasado de castas del cual provenian los criollos, en una forma de lavar sus manchas de origen ante una modernidad que imponía otros valores y sujetos, como los ciudadanos y el pueblo"69.

Entonces, la nación apareció en la Segunda República como el nuevo soporte soberano, una vez la Revolución logró imponerse sobre los regalistas. Claro está que un soporte artificial, una nación "creada para asegurar institucionalmente los intereses libertadores comunes de Venezuela y Nueva Granada, por tanto, creada por consideraciones de necesidad y de interés reciproco"70. Una nación que, dejaria de ser artificial, una vez el Estado la consolidase, a diferencia de lo acaecido en Europa.

Esto se puede ver, con alguna claridad, en dos casos. El primero, las cartas, las proclamas y las leyes que unieron a los pueblos de Venezuela y de la Nueva Granada en la nación de Colombia, entre 1819-182171. Entre dichos documentos se encuentra la "Ley fundamental de la unión de los pueblos de Colombia" del 12 de julio de 1821, artículo $1^{\circ}$ : "Los pueblos de la Nueva Granada y Venezuela quedan reunidos en un solo cuerpo de Nación, bajo el pacto expreso de que su

67 Inicialmente, la Constitución de Cádiz fue rechazada por las juntas rebeldes bajo el criterio de que era una norma que amparaba el despotismo y el absolutismo, pero una fue proscrita en 1814, la misma Constitución empezó a gozar de buena fama entre los revolucionarios, quienes la vieron como una norma tan sabia que el déspota monarca absolutista de Fernando no podía soportar. Cfr. Botero, Andrés, "Una sombra en la noche: en torno al constitucionalismo gaditano y la Nueva Granada", op. cit.

68 Botero, Andrés, Modelo de lectura del constitucionalismo provincial hispanoamericano: origen del constitucionalismo antioqueño, op. cit., pp. 230-231.

69 Almario, Oscar, "Del nacionalismo americano en las Cortes de Cádiz al independentismo y nacionalismo de Estado en la Nueva Granada”, 1808-1821, op. cit., p. 209.

70 König, Hans-Joachim, “Nación-Colombia”, op. cit., p. 912.

71 De la compilación de dichos documentos ("Documentos sobre la invención de una nueva nación que se llamaría Colombia, selección y transcripción de documentos de Armando Martinez Garnica", Revista Memoria, Archivo General de la Nación (Bogotá-Colombia), n 16, 2017, pp. 120143; König, Hans-Joachim, "Nación-Colombia", op. cit., pp. 912-916), queda en claro el paso del concepto "pueblo" al de "nación", de la siguiente manera: los pueblos de Venezuela y de la Nueva Granada deciden unir sus provincias para la creación de la nación de Colombia, la cual, una vez instaurada, pasa a ser el soberano. 
Gobierno será ahora y siempre popular representativo". Y el artículo 2: "Esta nueva Nación será conocida y denominada con el título de REPÚBLICA DE COLOMBIA". El segundo, la Constitución de 1821, en el llamado del Congreso General a los colombianos, que precede a dicha Carta: "Colombianos. El más ardiente deseo de todos y cada uno de vuestros representantes ha sido cumplir fielmente con los altos deberes que les habéis encargado, y creen haber llenado tan sagradas funciones al presentaros la Constitución que ha sido sancionada por el voto general. En ella encontrareis que sobre la base de unión de pueblos que antes formaron diferentes Estados se ha levantado el edificio firme y sólido de una nación cuyo Gobierno es popular representativo, y cuyos poderes, Legislativo, Ejecutivo y Judicial, exactamente divididos, tienen sus atribuciones marcadas y definidas, formando, sin embargo, un todo de tal suerte combinado y armonioso, que por el resultan protegidas vuestra seguridad, libertad, propiedad e igualdad ante la ley (...) Pero lo que vuestros representantes han tenido siempre a la vista, y lo que ha sido el objeto de sus más serias meditaciones, es que esas mismas leyes fuesen enteramente conformes con las máximas y los dogmas de la Religión Católica, Apostólica, Romana, que todos profesamos y nos gloriamos de profesar: ella ha sido la Religión de nuestros padres, y es la Religión del Estado; sus ministros son los únicos que están en libre ejercicio de sus funciones, y el Gobierno autoriza las contribuciones necesarias para el Culto Sagrado.// E1 Congreso general en sus deliberaciones no ha tenido otras miras que el bien común y el engrandecimiento de la nación".

Y más claro aún en dicha Constitución el título I (De la nación colombiana y de los colombianos), Sección I (De la nación colombiana), artículo $1^{\circ}$ ("La nación colombiana es para siempre e irrevocablemente libre e independiente de la monarquía española y de cualquier otra potencia o dominación extranjera; y no es, ni será nunca, el patrimonio de ninguna familia ni persona"), artículo $2^{\circ}$ ("La soberanía reside esencialmente en la nación. Los magistrados y oficiales del Gobierno, investidos de cualquiera especie de autoridad, son sus agentes o comisarios, y responsables a ella de su conducta pública") y artículo $3^{\circ}$ ("Es un deber de la nación proteger por leyes sabias y equitativas la libertad, la seguridad, la propiedad y la igualdad de todos los colombianos").

Pero una vez explotó esa "nación" artificial en 1830, al separarse Venezuela, Colombia y Ecuador, se reconstruyó este concepto para ser asimilado a la nueva realidad política: nación identificada con el Estado neogranadino o colombiano, la nueva patria de los ciudadanos del territorio central de la antigua Gran Colombia. Lo que explica, en buena medida, la sinonimia en los documentos jurídico-politicos de entonces entre nación, Estado y patria ${ }^{72}$. Una nación, dicho con otras palabras, que debía ser construida, para que dejase su rastro artificial, por el Estado, asunto para el cual la historiografia, patriotera como ninguna, ayudó a lo largo del siglo XIX. Pero no hay que desviarse. Hay que pasar a los textos constitucionales.

En la Constitución colombiana de 1830 puede verse lo anterior en su artículo $1^{\circ}$ ("La nación colombiana es la reunión de todos los colombianos bajo un mismo pacto político"), artículo $2^{\circ}$ ("La nación colombiana es irrevocablemente libre e independiente de toda potencia o dominación extranjera, y no es ni será

72 König, Hans-Joachim, “Nación-Colombia”, op. cit., p. 915. 
nunca el patrimonio de ninguna familia ni persona), artículo $3^{\circ}$ ("La soberanía reside radicalmente en la nación. De ella emanan los poderes políticos, que no podrán ejercerse sino en los términos que establece esta Constitución”), artículo 6' ("La Religión Católica, Apostólica, Romana es la religión de la República") y artículo $7^{\circ}$ ("Es un deber del Gobierno, en ejercicio del patronato de la Iglesia colombiana, protegerla y no tolerar el culto público de ninguna otra), entre otros.

En este sentido, durante la Segunda República, el pueblo dejó de ser soberano, y pasó a ser sinónimo de "población"73, la cual quedaba a merced de la instrucción y la formación del Estado, soberano por la nación, y de la Iglesia, soberana por Dios.

Se concluye: la poca presencia en los textos constitucionales provinciales durante la Primera República del concepto de nación, también se explica por la ideología militar y política de aquel entonces, que puso su acento en lo provincial, lo local e, incluso, lo familiar, antes que en los intereses colectivos de la Nueva Granada. Entonces, el soberano no podía ser una "nación católica" (cosa que además remitiría a Cádiz, esto es, a la España de la que se independizaban las provincias neogranadinas), sino un "pueblo católico provincial". La identidad colectiva, germen de la nación como entidad soberana, se fortaleció posteriormente entre los revolucionarios sobrevivientes, tras el fracaso bélico y político de la Primera República. El concepto de nación se convirtió pues en un ideario muy eficaz para una guerra intensiva moderna, pues desplazaba las disputas provinciales, locales y familiares, a favor de una ficción motivante (pues daba ánimos para continuar una guerra cada vez más intensiva) a la vez que incluyente (pues unía las facciones domésticas en un solo cuerpo político): la nación, la Gran Colombia. Esto último facilitó el tránsito de una soberanía del "pueblo católico provincial" durante la Primera República, a una de la "nación católica" en la Segunda.

\section{EL PUEBLO-NACIÓN CATÓlico}

Pero el tema no se limitó a establecer, aunque sea semánticamente, la entidad soberana. Sea pueblo o nación, tenían un calificativo muy importante en la época: católico. De esta forma emergió el discurso constitucional de un "pueblo católico" como el depositario de la soberanía según el constitucionalismo provincial, algo aparejado con el discurso de "nación católica" que impregnó el constitucionalismo normativo gaditano ${ }^{74}$. "Salvo rara excepción, todos los

\footnotetext{
73 Garrido, Margarita y Luz, Martha, "Pueblo - Colombia”, op. cit., p. 1184-1186.

74 Sobre el concepto de "nación católica" en las Cortes y Constitución de Cádiz, desarrollado por Portillo Valdés, existe un interesante debate científico. A diferencia de Portillo, quien ve en el uso del concepto de nación rastros clarísimos de tradición y conservadurismo, Fernández considera que dicha interpretación es cierta si se parte de un análisis estrictamente normativo, pero si se analizan otras fuentes como las doctrinales y los debates en Cortes la respuesta sería otra: que el uso del concepto de nación fue el resultado de una transacción entre liberales y conservadores, y no el predominio de los últimos sobre los primeros (Fernández Sarasola, Ignacio, "La Constitución española de 1812 y su proyección europea e iberoamericana", Fundamentos, $\mathrm{n}^{\circ} 2$, 2000 , pp. 359-457). Además, Fernández considera que los liberales españoles defendian la laicidad del Estado y la libertad religiosa, pero estas ideas no se llevaron a cabo para poder así transigir con los intereses de los realistas, quienes defendieron el patrón católico en lo político. El debate se extiende igualmente a la pregunta sobre qué fue primero en la Constitución gaditana: ¿La nación o el individuo? Para Portillo la respuesta está de lado de la nación (Portillo Valdés,
} 
hombres que promovieron el movimiento emancipador y todos los documentos que produjeron se esforzaron en declarar enfáticamente su adhesión a la religión católica, inclusive los más jacobinos. Más aún, se la estableció generalmente como religión del Estado y, aun más, se proscribieron todas las otras de manera expresa"75. Un ejemplo de esta característica puede encontrarse en la Constitución de la República de Cundinamarca de 1812, Título I, Artículo 1: "La Religión Católica Apostólica Romana es la única Religión de este Estado"; y Artículo 4 "En este Estado no se permite otro culto público, ni privado"76. Y con gran énfasis en el artículo 15 del Título II: "El juramento que deben prestar todos los Funcionarios al ingreso en su ministerio será en la fórmula siguiente: ¿Juráis á Dios nuestro Señor por la señal de Cruz guardar y defender la Religión Católica, procurar y sostener la libertad de la República, guardar fielmente esta Constitución y cumplir con exactitud los deberes da tu empleo? Sí juro"77.

Entonces, podría así afirmarse que el júbilo constitucional provincial tuvo un fuerte componente simbólico, puesto que las constituciones provinciales no fueron tanto un motor de modificación radical de las relaciones (políticas, sociales $\mathrm{y}$ económicas) a partir de ideas liberales (aunque produjeron algunas modificaciones de la realidad) como sí un documento que acreditaba el cambio de la titularidad del poder, de unas autoridades escogidas en la Península o en Santa Fe de Bogotá (por parte de las autoridades virreinales), a una junta de criollos que se autoconsideraron como legítimos representantes de la soberanía provincial y, por ende, del pueblo católico que fundaría el Estado que ellos mismos regirian.

José María, Revolución de nación: orígenes de la cultura constitucional en España, 1780-1812, op. cit., p. 18). Para Fernández el individualismo está en la base de la Constitución de Cádiz y la nación tiene, precisamente, que proteger los derechos individuales. Este debate toca las constituciones provinciales neogranadinas, ante lo cual podría afirmarse que el concepto de pueblo-católico existió normativamente, pero ello no niega otras conceptos de soberanía, ni la similitud entre nación y pueblo en lo que atañe a sus significados, ni la presencia de ideas liberales a la par de conservadoras; lo anterior ratifica lo que se ha señalado en varias oportunidades sobre la complejidad, la multicausalidad y la tensión de fondo en lo constitucional de aquel período.

75 Romero, José Luis, Situaciones e ideologías en América Latina, Universidad de Antioquia, Medellin, 2001, p. 74.

76 Igualmente, la Constitución de Mariquita de 1815, específicamente en el Título 3, Artículo 1: "La Religión Católica, Apostólica Romana, es la única Religión de este Estado y no se permitirá otro culto público ni privado". También, la Constitución de la República de Tunja de 1811, especialmente en el Artículo 7 del Capítulo 3 de la Sección Primera (Del Poder Legislativo): "Su primer y sublime objeto [el de la Legislatura], será mantener por medio de las leyes sabias la santa Religión Católica, Apostólica Romana en toda su pureza e integridad".

77 En un estudio anterior (Botero, Andrés, "De la religión del juramento al juramento legal: conclusiones de un estudio sobre la evolución del juramento procesal en Colombia durante el siglo XIX", Precedente: Revista de la Universidad ICESI (Cali-Colombia), vol. 2, 2013, pp. 9-46) se pone en evidencia que el juramento religioso, fundamento de las obligaciones tanto públicas como privadas en el Antiguo Régimen, empezó a ceder ante el juramento civil a partir del constitucionalismo de la Primera República para el caso neogranadino, dado que en el juramento exigido por las constituciones provinciales de la época siguió siendo religioso pero apareció en su fórmula el elemento Estado. Con el paso de los años, dicho elemento estatalista terminó por minimizar (o incluso expulsar) la remisión religiosa en la fórmula, aspecto que ya se ve con mayor claridad en la segunda mitad del siglo XIX. 
En el concepto de "pueblo católico" confluyeron pues unas esperanzas liberales y una visión conservadora. Asimismo, aparecieron las libertades armonizadas con un criterio que ha sido considerado como factor de unidad nacional hispanoamericana: el catolicismo, donde pueblo o nación identificó, en ese contexto, una identidad religiosa concreta a partir del origen físico de un individuo (ser español o neogranadino sería, por ende, ser católico), en comparación con los orígenes y las creencias de otros individuos ${ }^{78}$. De esta forma el liberalismo católico a ambos lados del Atlántico intentó integrar la ideología liberal política con la religiosa, a partir de la consagración de la "nación católica" (Cádiz y Segunda República) o el "pueblo católico" (Primera República), como sujetos de soberanía ${ }^{79}$. Y, por último, ya en las juntas rebeldes, fue una manera de ser presentado un modelo político de supremacía criolla enfrentado discursivamente (aunque no tanto realmente) a un modelo colonial, indiano, calificado por ellos como absurdo, injusto y tiránico.

Antes de nada, debe procederse a establecer la verdadera dimensión politica del calificativo "católico" que acompañó la entidad soberana tanto en Cádiz, como en la Primera y Segunda República. Portillo, estudiando la Constitución gaditana, afirma que la religión que se protegió constitucionalmente no era la del Estado sino la de la nación, es decir, el catolicismo era propiamente una religión nacional y la nación era su protectora, sin mediar para ello la estructura monárquica, pues se trataba de un simbolismo de libertad y soberanía frente a la invasión francesa, de un lado, y frente a los borbones, del otro ${ }^{80}$. Esto es igualmente cierto, mutatis mutandis, para el caso hispanoamericano en lo que respecta a su pretensión de independencia y de relación directa con la religión sin mediación de estructura politica peninsular; sin embargo, en lo atinente a la religión para con la provincia misma, el catolicismo pasó a ser religión de Estado pues el "pueblo" constituyente no era otro que una junta de criollos que tomó las riendas en momentos decisivos: el Estado, como ya se dijo, debía aquí consolidar a su soberano terrenal y sobrenatural.

En consecuencia, la enunciación del catolicismo como religión única, verdadera, constitucionalmente protegida, etc., en todas las constituciones provinciales de la Primera República, tuvo diversos sentidos bajo una lógica simbólica: el primero fue mostrar una relación directa con la fe (y, por ende, con la estructura institucional de sostenimiento de la misma) sin intermediación española (ya no es sólo un acto político soberano frente a la monarquía, como es el caso de Cádiz, sino incluso contra la misma "nación católica" que allí se gestó), y el segundo fue el de querer continuar, alegando la catolicidad del soberano, con las prebendas que gozaba España, en virtud del patronato, como protector de la

78 Lo cual encaja, además, en lecturas biblicas. En la Biblia "nación” es etnia, ethnos en griego, goy en hebreo, equivalente a pueblo. Schallman, Lázaro, Diccionario de hebraismos y voces afines, Israel, Buenos Aires, 1952.

79 Portillo Valdés, José María, Revolución de nación: orígenes de la cultura constitucional en España, 1780-1812, op. cit., p. 399.

80 Portillo Valdés, José María, Revolución de nación: origenes de la cultura constitucional en España, 1780-1812, op. cit., p. 443-459. 
fe, lo que permitiria al naciente Estado provincial un eficaz control territorial como lo tuvo, gracia a la religión, la monarquía ${ }^{81}$.

No obstante, como ya se dijo, desde el mismo momento en que el "pueblo provincial" se constitucionalizó como Estado, la religión pasó a ser también de Estado, a diferencia del caso gaditano. Resulta que el único que podría reclamar para sí el deber de protección de la religión por fuera de la "nación española" era el rey (de allí la urgencia en la Constitución de Cádiz de marcar que la religión era nacional y no del monarca ni del Estado que el rey regentaría), pero al independizarse la Nueva Granada, no era necesario un acto soberano de supremacia protectora del pueblo frente al naciente Estado en tanto éste apenas iba a ser organizado, con lo que el "pueblo" se deslizó constitucionalmente al estatalismo mediando la religión. La religión, en el constitucionalismo provincial, pasó a ser en papeles tanto del pueblo como del Estado ${ }^{82}$.

Además, teniendo en cuenta la fuerte influencia religiosa en toda Hispanoamérica, no podria esperarse que las ideas liberales fuesen radicales en lo que respecta a la libertad de cultos. Este rechazo a la tolerancia religiosa permitió tender un puente de comunicación entre los liberales con los conservadores presentes en las juntas criollas, quienes venían desempeñándose generalmente en cargos públicos en los ayuntamientos de las ciudades coloniales. La religión católica, consecuentemente, no fue concebida, ni siquiera por los más radicales revolucionarios, como un motor de esclavización de la inteligencia humana; a la par que con ella, se creyó se evitarian los extremos jacobinos que incluso los mismos liberales hispanoamericanos criticaban de la Revolución Francesa, y se marcó de esta manera una diferencia entre lo que constituiría la Ilustración hispanoamericana con el anticlericalismo de la Revolución Francesa y con la tolerancia de la ilustración kantiana: "He tratado del punto principal de la Ilustración, a saber, la emancipación de los hombres de su merecida tutela, en especial por lo que se refiere a cuestiones de religión; pues en lo que atañe a las ciencias y las artes los que mandan ningún interés tienen en ejercer tutela sobre sus súbditos $y$, por otra parte hay que considerar que esa tutela religiosa es, entre todas, la más funesta y deshonrosa" 83 .

81 Bajo la bandera de la defensa de la religión, los monarcas españoles lograron un control directo sobre América evitando la intromisión de la sede pontificia. Al respecto: Sánchez, Bella Ismael, "Documentos vaticanos sobre la recopilación de Indias de 1680", Historiografia y bibliografia americanistas, EEHA-Sevilla, vol. XXXI, n 1, 1987, pp. 63-80.

82 Dice así el artículo 1, de la sección primera del título I de la Constitución antioqueña de 1812: "El pueblo de la provincia de Antioquia y sus representantes reconocen y profesan la Religión Católica, Apostólica, Romana como la única verdadera: ella será la religión del Estado”.

83 Kant, Immanuel, Filosofía de la historia, Fondo de Cultura Económica, Bogotá, 1994, p. 36. en la misma línea: Rousseau [Rousseau, Jean Jacques, El contrato social, op. cit., Libro IV, Capítulo 8 (p. 64-75)], Voltaire [Voltaire, Tratado de la tolerancia, Crítica, Barcelona, 1977, p. 70] y Montesquieu [Montesquieu, Del espíritu de las leyes, op. cit., pp. 321-329]. En el propio Kant se refleja un marcado optimismo histórico, fundamentalmente luego de 1790, fruto de su admiración a los hechos revolucionarios y a las "luces" europeas, lo que le lleva a poner al derecho como un agente decisivo en la construcción de la nueva república (Cfr. López-Domínguez, Virginia, "Sobre la evolución de la filosofía kantiana de la historia", Logos, Anales del seminario de metafísica, $\mathrm{n}^{\circ}$ 37, 2004, pp. 89-110). Esta filosofia ilustrada-kantiana sirve de telón de fondo a los momentos de júbilo del primer constitucionalismo neogranadino. 
De este modo, al reclamarse políticamente la relación directa puebloreligión-Estado, este último pudo pedir para sí, como efectivamente está en papeles, una obediencia irrestricta, lo que recuerda las palabras de Napoleón a Pezet de Lozère: "Yo no veo en la religión el misterio de la Encarnación, sino el misterio del orden social" 84 . Así, no fue gratuito que la Constitución antioqueña del 12, que ha sido el ejemplo más recurrente, expresó que los deberes de los ciudadanos estaban amparados por la religión (artículo 1 y 2, sección tercera, título I) y, por tanto, que "ninguno es hombre de bien, si no es franco, y religiosamente observador de las leyes"85. La ley estatal, entonces, debía ser cumplida no sólo como acto del poder soberano, sino como asunto religioso, pues el soberano es católico y así se reconoce la soberanía popular. Se empezó a fermentar así el modelo legicentrista moralista que tanto efecto tendrá en América Latina.

Además, la vinculación pueblo-religión, que evitaría la intermediación española a la vez que reafirmaría el carácter fuertemente católico de la sociedad criolla hispanoamericana ${ }^{86}$ que pretendia hacer Estado, dio fundamento a los derechos que se reclamaban en contra del español (en especial las declaraciones de derechos recepcionadas de la Revolución Gloriosa, Estadounidense y Francesa) así como el derecho que en últimas fue visto como el superior y que garantizaría a los criollos la toma del poder: la propiedad. Este derecho fue considerado desde los preliminares de la Constitución antioqueña del 12 como sagrado, junto a la libertad, la igualdad y la seguridad. Pero en el desarrollo del texto constitucional terminó siendo el derecho básico exigido para reclamar los otros, pues sólo gozaría de todas las libertades políticas el propietario, considerado por ser tal como el verdadero interesado en la buena administración del Estado, idea muy generalizada en ese entonces ${ }^{87}$. De esta forma, al considerarse el pueblo como católico, y la propiedad como derecho divino, se tomó como propia y ajustada a la fe la exigencia de la propiedad como requisito de participación política, por lo que el concepto de ciudadano universal (es decir, una ciudadanía otorgada sin atender el género, la propiedad, el nivel cultural, etc.) no se encuentra en el hiperconstitucionalismo provincial ${ }^{88}$.

84 Citado por Cassagne, Inés, “Corrientes religiosas en el siglo XVIII en Francia", en AA.VV., La codificación: raices y prospectiva. I, UCA, Buenos Aires, 2003, p. 55.

85 Título I, sección tercera, artículo 5. En igual sentido, título IV, sección primera, artículo 8, Constitución de 1812, que fija como obligación del Presidente velar para que se las leyes se ejecuten y observen religiosamente por los habitantes, empleados, jueces y tribunales de la provincia.

86 Puesto de manifiesto de diversas maneras como, por ejemplo, las prácticas religiosas, la mentalidad social y el rito funerario. González Cruz, David, Prácticas religiosas y mentalidad social en la Huelva del siglo XVIII, Universidad de Huelva, Huelva, 1999 (edición electrónica).

87 Aljovín de Losada, Cristóbal, "La Constitución de 1823”, en Scarlett O'phelan Godoy (ed.), La independencia del Perú: de los borbones a Bolivar, Pontificia Universidad Católica del Perú, Lima, 2001 , p. 354.

88 Incluso el concepto de ciudadano universal es posterior. Jaramillo Uribe, Jaime, El pensamiento colombiano en el siglo XIX, op. cit., p. 123. Además, se alude a la Primera República como el periodo del hiperconstitucionalismo, en tanto proliferaron las constituciones como medio simbólico de cimentar los nuevos poderes. Cfr. Botero, Andrés, Modelo de lectura del constitucionalismo provincial hispanoamericano: origen del constitucionalismo antioqueño, op. cit., pp. 101-131. Uribe Urán, Víctor, “Constitución - Colombia”, en Javier Fernández Sebastián (Dir.), 
Es por ello que Lynch sostiene:

\begin{abstract}
"Así, la nación fue una nación criolla, no una nación popular: sus instituciones estaban destinadas a proteger los intereses criollos, y se identificaban con la república constitucional. La constitución, desde luego, al imponer restricciones a los analfabetos y no propietarios, privaba a la masa del pueblo del derecho al voto, y la defensa de la constitución se convirtió en un proceso en el que no se extendía la participación política sino que se restringía y se prohibia que otros grupos sociales se uniesen a la nación política" 89 .
\end{abstract}

\title{
VI. PUEBLO CATÓLICO Y CIUDADANO PROPIETARIO
}

El soberano de la Primera República era, pues, un entramado discursivo y conceptual, denominado vaga y astutamente como "pueblo". Este se asumió como católico, lo cual fue su característica de identidad (planteándose así como una diferencia más con la Revolución Francesa), a la vez que su fortaleza política, por las razones ya argüidas en páginas anteriores. De esta forma, la idea de "libertad política" en un contexto de fuerte raigambre de la cultura católica fue tomada como capacidad para convertirse el "pueblo provincial" en sujeto soberano y constituyente dado que protegió a quien terminó atribuyéndose el derecho sagrado reclamado ${ }^{90}$, con lo que no se trató de una simple contradicción entre la libertad reclamada constitucionalmente y la consagración de una religión nacional excluyente, como lo creyó Uribe ${ }^{91}$.

Ante la consideración constitucional del pueblo católico como el soberano, el discurso político liberal (Estado de derecho, división del poder, principio de legalidad, etc.) terminó concertando con las prácticas histórico-conservadoras sin renunciar del todo a la reivindicación de unos derechos que de naturales pasaron a ser considerados sagrados, pero cuya aplicación debería ser mediada por un legislador igualmente católico (en tanto religión de Estado). No de otra manera podrian entenderse las constituciones provinciales en general y la antioqueña de 1812 en particular, cuando señaló que "la declaración de los derechos del hombre contiene las obligaciones de los legisladores" (artículo 1, sección tercera, título I).

Y teniendo presente que la propiedad fue erigida como un derecho sagradocatólico, el "pueblo" que se consagró como protector de la religión debería velar igualmente por la protección de la propiedad. Por tanto, si la propiedad pasó a ser eje central de la actividad politica, ya se comprende por qué los ilustrados inicialmente y los rebeldes afirmaron constantemente que el progreso y los demás sueños ilustrados serían alcanzables con una política de acceso a la

Diccionario politico y social del mundo iberoamericano, La era de las revoluciones, 1750-1850, Iberconceptos I, Fundación Carolina y otros, Madrid, 2009, pp. 366-368.

89 Lynch, John, Hispanoamérica 1750-1850: Ensayos sobre la sociedad y el Estado, Universidad Nacional de Colombia, Bogotá, 1987, p. 97. En similar sentido: Carrera Damas, Germán, “El nacionalismo latinoamericano en perspectiva histórica", Revista Mexicana de Sociología, $\mathrm{n}^{\circ} 38$, 1976, pp. 783-791. Jaramillo Uribe, Jaime, El pensamiento colombiano en el siglo XIX, op. cit., p. 122-125.

90 Idea presente en: Portillo Valdés, José María, Revolución de nación: origenes de la cultura constitucional en España, 1780-1812, op. cit., p. 399.

91 Uribe Vargas, Diego, Las constituciones de Colombia, Tomo I, Cultura Hispánica, Madrid, 1977 , p. 63. 
propiedad privada (de allí el fundamento ideológico de eliminar los resguardos para distribuir estas tierras entre los indios). Frente a los ilustrados se tiene el caso emblemático de Rousseau (en su célebre "Discurso sobre el origen de la desigualdad entre los hombres", de 1755), quien acusó a la desigualdad económica, fruto de la propiedad privada, como la culpable de los males sociales. Ante esto, Jovellanos consideró que era la desigualdad -fruto de la mala distribución de la tierra- y no la propiedad en sí misma, la causa del atraso moral y económico de España, por lo cual criticó las políticas de concentración de las tierras cultivables como el principal obstáculo del desarrollo agrícola de la nación ${ }^{92}$. Creyeron pues, las diferentes escuelas del liberalismo español (como las Sociedades de amigos del pais) que una mejor distribución de la propiedad sería la fuente del patriotismo que se reclamaba para el progreso ${ }^{93}$, lo que condujo a aceptar como premisa válida la exigencia del acceso a la propiedad para el cabal ejercicio de las libertades políticas ${ }^{94}$ (la propiedad sagrada como el motor de la libertad) ${ }^{95}$, pero no así de los deberes, que estos sí eran interpretados de manera amplia en cuanto sus destinatarios (para cobijar en la red de deberes con el nuevo soberano al desposeído), pero sin abandonar las esperanzas de una reforma agraria que permitiese, en el caso americano, a indios, negros y mestizos el acceso a la ciudadanía y a la civilización al poder ser propietarios. De esta forma, el debate de los liberales fervientes a finales de la Colonia y durante el hiperconstitucionalismo provincial de la Primera República, no versó sobre la concesión o no de las libertades políticas a las castas, sino de permitir -por lo menos legalmente- su acceso a la propiedad sagrada.

\section{LA NACIÓN-PUEBLO CATÓLICO Y LA MODERNIDAD}

La modernidad jurídica entró a Hispanoamérica de la mano con ideales liberales (en especial por el anhelo de Estado) y conservadores (por la religión y el historicismo de base); ejemplo de ello fue la consagración en el constitucionalismo provincial del "pueblo católico" como el entramado político soberano. En este caso coincidieron, como se ha dicho, la tradición católica con visiones liberales, incluso con posturas que hoy pueden considerarse como proto-

92 Citado por: Rodríguez, Mario, El experimento de Cádiz en Centroamérica, 1808-1826, Fondo de Cultura Económica, México, 1984, p. 17.

93 Rodríguez, Mario, El experimento de Cádiz en Centroamérica, 1808-1826, op. cit., p. 44.

94 “Tendrá derecho para elegir y ser elegido todo varón libre, padre o cabeza de familia, que viva de sus rentas u ocupación, sin pedir limosna, ni depender de otro... a más de esto los apoderados deberán tener un manejo, renta o provento, que equivalga a doscientos pesos" Artículo 7, sección segunda, título tercero, Constitución antioqueña de 1812. Este tipo de exigencia fue común en el constitucionalismo hispanoamericano. Al respecto dice Lynch: "Esto equivalia virtualmente a anular los derechos politicos de las clases populares" Lynch, John, Hispanoamérica 1750-1850: Ensayos sobre la sociedad y el Estado, op. cit., p. 113. Para el caso de Cádiz: "Conforme a la Constitución de 1812, en las Españas no todos los españoles disfrutaban de los mismos derechos ni bastaba vivir en territorio español para disfrutar de los beneficios y las libertades que aquel Código garantizaba. El goce pleno de aquellos derechos está reservado al ciudadano..." (Labra, Rafael María de, América y la Constitución española de 1812: La Cortes de Cádiz de 1810-1813, Tipografia del Sindicato de la Publicidad, Madrid, 1914, p. 141).

95 Como fue el caso de Pablo de Olavide y León de Arroyal (Portillo Valdés, José María, Revolución de nación: origenes de la cultura constitucional en España, 1780-1812, op. cit., pp. 135138). 
positivistas, lo cual se tradujo en la práctica del quehacer científico-católico de criollos muy activos en el proceso hiperconstitucional, como lo fueron Félix de Restrepo y Francisco José de Caldas, quienes vieron en la ciencia y en la historia un camino de progreso coincidente con los nuevos cambios políticos y con los dogmas religiosos ${ }^{96}$, lo que les trajo no pocas contradicciones, como lo fue la defensa de Caldas (fundador de una escuela de ingenieros militares en Medellín), de que el clima interferia en la conducta moral de los hombres (similar a lo dicho por Montesquieu y Voltaire ${ }^{97}$ ) y que implica en el fondo un determinismo que atentaba contra el dogma teológico del libre albedrío.

Esta función moderna del "pueblo católico" pudo deberse, en alguna medida, a la concepción erasmista98, que tuvo efectos, aun por estudiar a profundidad, en el proceso revolucionario, pero que no podian ser mencionados expresamente en proclamas y documentos públicos pues ello implicaría una pérdida del valor simbólico del discurso si se compara con el efecto que se obtenía alegando a otros autores más aceptados (en especial los escolásticos y los ilustrados tanto españoles como napolitanos).

La llegada de la modernidad política implicó el reconocimiento del "pueblo católico" como el verdadero agente político del constitucionalismo provincial, pues en su nombre la junta criolla se independizó de toda autoridad política metropolitana ${ }^{99}$. Esta entidad política, que se adhirió a la modernidad temprana y al liberalismo político sin renunciar a elementos conservadores de identidad (que son excelentes motores ideológicos de cohesión, control y motivación social, por la convicción compartida de que se estaba ante la única religión verdadera), se derramó entre los individuos que esta misma nación escogió para ser sus portavoces, según calidades católicas apreciadas, tales como ser: vecino a la parroquia (unidad electoral), padre de familia (con lo que ello implica en la familia católica), propietario (por tanto preocupado por el bienestar de la tierra a la que está anclado en una relación que no se agota en lo económico y, además, aportante a los gastos de la Iglesia local), varón y "patriota", es decir, creyente religioso de una soberanía que ya no sólo dependía del "pueblo", como parecía inicialmente, sino de una religión que le daría forma al pueblo para que éste la reconociese como propia. Así, la ciudadanía plena terminó perteneciendo, en los términos señalados, al "pueblo católico" soberano, que tendría la potencia

96 Jaramillo Uribe, Jaime, El pensamiento colombiano en el siglo XIX, op. cit., p. 319-340. Peralta, Jaime Andrés, Los novatores: la cultura ilustrada y la prensa colonial en Nueva Granada (1750-1810), op. cit., p. 76-81. Melo, Jorge Orlando, "Historia - Colombia" en Javier Fernández Sebastián (Dir.), Diccionario politico y social del mundo iberoamericano, La era de las revoluciones, 1750-1850, Iberconceptos I, Fundación Carolina y otros, Madrid, 2009, pp. 621-622.

97 El determinismo del clima jugó, además, en contra de los americanos (incluyendo a los criollos), quienes fueron considerados inferiores por las condiciones geográficas del Nuevo Continente. Esto produjo una reacción americanista expresada en la publicidad de las bondades geográficas de América (piénsese en la Expedición Botánica, con: Mutis, José Celestino, El Arcano de la Quina [1828], Cádiz: Diputación de Cádiz, 2008), lideradas, como era de esperarse, por los mismos criollos, con el fin de negar tal determinismo. Cfr. Pérez Collados, José María, "La recepción de los principios politicos de la ilustración en la Nueva España”, en Homenaje al profesor Alfonso García-Gallo, op. cit., pp. 253-258. Feres Junior, João, "El concepto de América: ¿concepto básico o contraconcepto?", op. cit., pp. 55-56.

98 Jaramillo Uribe, Jaime, El pensamiento colombiano en el siglo XIX, op. cit., p. 340.

99 El 11 de agosto de 1813. Archivo Histórico de Antioquia, Tomo 827, Documento 13054. 
emancipadora, entre otras cosas por ser sagrada, frente al sistema virreinal y al monárquico. El "pueblo católico" no seria, en consecuencia, el universo ciudadano pero sí un motor suficiente para la Independencia ${ }^{100}$.

Estos hombres escogidos por las constituciones provinciales, que eran la boca de expresión y de querer de una entidad tomada como indivisible y sagrada, no vinieron a ser otros que los criollos que, por su condición socio-económica, constituían las oligarquías locales, lo cual generó una conciencia un poco ambivalente en las castas, quienes anhelando cambios reales (especialmente entre los mestizos) observaron cómo las estructuras de mando económicas que habian conocido en sus faenas laborales pasaron ahora a ser, por demás, las estructuras de poder político que los incluyeron en un "pueblo" pero al que no tenian capacidad de expresarlo, de votarlo, pero sí el deber de obedecerlo. Esta ambivalencia de las castas, se representó en no pocos casos con la actitud de moderada alegría o, en el peor de los casos, de disimulada indiferencia, frente al primer proceso independentista, al que celebraron por igual que a las fiestas en homenaje a Fernando VII, pero que a la postre, una vez agravada la crisis económica y de seguridad, terminaron todos por tomar partido cuando la guerra se radicalizó al cambiar la doctrina militar, entre otras cosas, a partir de 18141815. En esos momentos, algunos optaron por guardar los lazos de fidelidad al rey, que comprometió en mayor medida a los indios (sin generalizar, claro está); mientras que otros prefirieron seguir a las estructuras de mando económica, en un sentido amplio de la palabra, ya existentes, pues así creyeron que arriesgaban menos que tomando las armas a favor de las huestes españolas de Morillo, que entraron en el territorio en 1815, y de las autoridades metropolitanas, cuyo motor de decisiones se ubicaba más allá del Atlántico.

De esta forma, en la Primera República, los intereses del "pueblo católico" terminaron siendo los intereses pensados desde el criollismo hacia los demás estamentos, convencidos de que eso motivaría la expresión patriótica requerida para sobrevivir.

Fueron estos mismos criollos quienes, en virtud de esa asociación puebloreligión, se consideraron habilitados para perseguir los elementos que atentaban contra tan "natural" equilibrio, condenando como no católico al no patriota101.

Se concluye: el "pueblo católico", en cuanto los derechos políticos, no fue un universo ciudadano, sino una comunidad de personas con las cualidades requeridas por el mismo soberano en cuanto a su linaje, sexo, identidad cultural, confesión religiosa y condición económica. El "pueblo" estableció así sus

100 Para Cádiz: Portillo Valdés, José María, Revolución de nación: origenes de la cultura constitucional en España, 1780-1812, op. cit., p. 18. Para Iberoamérica: Sá e Melo Ferreira, Fátima, "Entre viejos y nuevos sentidos: "pueblo" $y$ "pueblos" en el mundo iberoamericano entre 1750 y 1850", op. cit., pp. 1117-1138. Mientras en otros hemisferios la ciudadanía pretendió la homogeneidad legal y social (Lucas, Javier de, "Racismo y xenofobia: la respuesta del derecho", en Sami Naïr y Javier de Lucas, El desplazamiento en el mundo: Inmigración y temáticas de identidad, Ministerio de Trabajo y Asuntos Sociales, Madrid, 1998, p. 95), en la Nueva Granada sucedió algo bien diverso (König, Hans-Joachim, "Ciudadano - Colombia”, op. cit., pp. 235-240).

101 Archivo Histórico de Antioquia, Tomo 822, 12978, 1812. Lo firma José Antonio Gómez, presidente del Estado, creando una junta de seguridad y vigilancia, así como jueces e instancias entre cuyas funciones está la de perseguir los conventos antiamericanos. 
condiciones constitucionales para la libertad porque era sujeto esencial, por encima y antes que los individuos y los territorios ${ }^{102}$.

\section{CONCLUSIONES}

Si bien varios actores del proceso independentista neogranadino solian usar con cierta indistinción los términos "nación", "pueblo", "república", "constitución", "patria", etc., pueden verse en los textos constitucionales y los documentos de los colegios constituyentes de la Primera y la Segunda República ciertos usos diferenciados de los términos al momento de designar al soberano.

Atendiendo a lo anterior, este escrito se preguntó por el uso del concepto de "pueblo" en las constituciones provinciales de la Primera República y su abandono paulatino en los manifiestos jurídico-políticos de la Segunda. Esto se explicó a partir de tres elementos. El primero, que el "pueblo" permitió justificar de mejor manera la relación que de entrada se gestó entre el localismo y lo doméstico con las juntas independentistas; es decir, que afirmar la soberanía del "pueblo" significaba, en lenguaje de la época, defender los intereses familiares, locales y provinciales ante las nuevas instituciones politicas. De esta manera, los criollos, que fueron los principales actores del proceso hiperconstitucional, fueron los beneficiados del uso y del significado que se dio en su momento al "pueblo"103. El segundo que con dicho concepto se lograba generar el efecto de una oposición ante el enemigo, quienes durante la Primera República se fundaban en la Constitución de Cádiz que sí aludía a la nación bihemisférica como el soberano. Tercero, que el "pueblo" como soberano iba de la mano con la doctrina militar dominante en ese momento, de guerra entendido en la lógica del Antiguo Régimen; lo que, de otra vía, significó que el cambio de doctrina militar hacia la guerra moderna, propició el uso creciente del concepto "nación" pues justo esta

102 Portillo Valdés, José María, Revolución de nación: orígenes de la cultura constitucional en España, 1780-1812, op. cit., p. 18.

103 Para evitar malentendidos, los criollos no fueron los únicos agentes relevantes del proceso de Independencia, ni siquiera en la Primera República, como sí lo sugirió en su momento José Manuel Restrepo con su "Historia de la revolución de la República de Colombia en la América meridional" (Mejía, Sergio, La revolución en letras: La historia de la revolución de Colombia de José Manuel Restrepo (1781-1863), Universidad de los Andes y Universidad EAFIT, Bogotá-Medellín, 2007. Botero, Andrés, "Saberes y poderes: los grupos intelectuales en Colombia", Revista Pensamiento Jurídico, $\mathrm{n}^{\circ} 30$, enero-abril 2011, pp. 164-169). Este pensamiento de Restrepo (de que la Independencia fue un asunto criollo) debe matizarse fuertemente (Colmenares, Germán, "La historia de la revolución por José Manuel Restrepo: una prisión historiográfica", en Germán Colmenares, et al., La Independencia. Ensayos de historia social, Colcultura, Bogotá, 1986, pp. 7 23. Múnera, Alfonso, El fracaso de la nación: región, clase y raza en el Caribe colombiano (17171810), Banco de la República y El Áncora editores, Bogotá, 1998, pp. 13-28). Además, la cultura constitucional, eminentemente criolla, fue una parte, pero no la totalidad, del proceso independentista. Pero aún hace falta investigación sobre la participación de las castas en la revolución. Como dice Almario: "Es cierto que no contamos aún con una historia totalizante e inclusiva de todos los actores sociales y que como tal supere definitivamente el eurocentrismo y el nacionalismo como paradigmas de análisis, pero los esfuerzos en esa dirección ya son visibles en los trabajos que se ocupan de los indios, los negros y los libres de todos los colores y sus protagonismos respectivos durante la Independencia". Almario, Oscar, Castas y razas en la independencia neogranadina, 1810-1830: Identidad y alteridad en los orígenes de la Nación colombiana, Universidad Nacional de Colombia, Bogotá, 2012, p. 22. 
idea fomentaba los espíritus combativos en momentos en que el conflicto se intensificaba y se radicalizaban las partes en contienda.

Además, se sostuvo que el concepto de "pueblo", tal como fue usado en la Nueva Granada, no distaba mucho de lo que significaba el de "nación", de un lado; y como el "pueblo" soberano no podía desligarse de un acento hispanoamericano relevante hasta el día de hoy: la religión como legitimadora y legitimada de los procesos políticos y de la ciudadanía, del otro.

\section{BIBLIOGRAFÍA}

Aljovin de Losada, Cristóbal, "La Constitución de 1823", en Scarlett O'phelan Godoy (ed.), La independencia del Perú: de los borbones a Bolivar, Pontificia Universidad Católica del Perú, Lima, 2001, pp. 351-378.

Almario, Oscar, "Del nacionalismo americano en las Cortes de Cádiz al independentismo y nacionalismo de Estado en la Nueva Granada, 1808-1821", en Manuel Chust, e Ivana Frasquet (edit.), Los colores de las independencias iberoamericanas: liberalismo, etnia y raza, Consejo Superior de Investigaciones Cientificas, Madrid, 2009, pp. 197-219.

Almario, Oscar, Castas y razas en la independencia neogranadina, 1810-1830: Identidad y alteridad en los orígenes de la Nación colombiana, Universidad Nacional de Colombia, Bogotá, 2012.

Bacot, Guillaume, Carré de Malberg et l'origine de la distinction entre souveraineté du peuple et souveraineté nationale, Editions du CNRS, Paris, 1985.

Bandieri, Luis Maria, "Patria, Nación, Estado et quibusdam aliis", Revista Facultad de Derecho y Ciencias Políticas, vol. 37, $\mathrm{n}^{\circ}$. 106, 2007, pp. 13-53.

Blanco, Jacqueline, "La revolución de los colores y la limitación de los derechos politicos a los colombianos durante la temprana república", Revista Prolegómenos Derechos y Valores, vol. 20, n. 40, 2017, pp. 77-95.

Botero, Andrés, "De la religión del juramento al juramento legal: conclusiones de un estudio sobre la evolución del juramento procesal en Colombia durante el siglo XIX", Precedente: Revista de la Universidad ICESI (Cali-Colombia), vol. 2, 2013, pp. 946.

Botero, Andrés, "El pueblo católico criollo como un poder soberano en la Constitución antioqueña de 1812" en José Ramón Narvaez y Emilio Rabasa (edits.), Problemas actuales de la historia del derecho en México, Porrúa y Tecnológico de Monterrey, México, 2007, pp. 287-314.

Botero, Andrés, Modelo de lectura del constitucionalismo provincial hispanoamericano: origen del constitucionalismo antioqueño, Universidad de Medellín, Medellín, 2010.

Botero, Andrés, "Saberes y poderes: los grupos intelectuales en Colombia", Revista Pensamiento Jurídico, $\mathrm{n}^{\circ}$ 30, enero-abril 2011, pp. 161-216.

Botero, Andrés, "Una sombra en la noche: en torno al constitucionalismo gaditano y la Nueva Granada", Historia Constitucional, n 15, 2014, pp. 311-389. 
Carpintero, Francisco, "Los escolásticos españoles en los inicios del liberalismo político y jurídico", Revista de Estudios Histórico-Jurídicos, Sección Historia del Pensamiento Jurídico, no. XXV, 2003, pp. 341-373.

Carré De Malberg, Raymond, Teoría General del Estado, Fondo de Cultura Económica, México, 1978.

Carrera Damas, Germán, “El nacionalismo latinoamericano en perspectiva histórica", Revista Mexicana de Sociología, n 38, 1976, pp. 783-791.

Cassagne, Inés, "Corrientes religiosas en el siglo XVIII en Francia", en AA.VV., La codificación: raices y prospectiva I, UCA, Buenos Aires, 2003, pp. 39-57.

Chiaramonte, José Carlos, Nación y Estado en Iberoamérica. El lenguaje político en tiempos de la independencia, Sudamericana, Buenos Aires, 2004.

Colmenares, Germán, "La historia de la revolución por José Manuel Restrepo: una prisión historiográfica”, en Germán Colmenares, et al., La Independencia. Ensayos de historia social, Colcultura, Bogotá, 1986, pp. 7-23.

Constitución del Estado de Antioquia, sancionada por los representantes de toda la provincia y aceptada por el pueblo el 3 de mayo del año de 1812: Imprenta de D. Bruno Espinosa por D. Nicomedes Lora, Bogotá, 1812.

"Documentos sobre la invención de una nueva nación que se llamaria Colombia, selección y transcripción de documentos de Armando Martínez Garnica", Revista Memoria, Archivo General de la Nación (Bogotá-Colombia), n 16, 2017, pp. 120143.

Estrada Vélez, Sergio Iván, "La importancia de la historia constitucional para la comprensión del constitucionalismo contemporáneo", en Andrés Botero (edit.), Origen del constitucionalismo colombiano. Ponencias del III Seminario Internacional de Teoría General del Derecho, Universidad de Medellín, Medellín, 2006, pp. 197214.

Feres Junior, João, “El concepto de América: ¿concepto básico o contraconcepto?”, en Javier Fernández Sebastián (Dir.), Diccionario politico y social del mundo iberoamericano, La era de las revoluciones, 1750-1850, Iberconceptos I, Fundación Carolina y otros, Madrid, 2009, pp. 51-67.

Fernández Sarasola, Ignacio, “La Constitución española de 1812 y su proyección europea e iberoamericana", Fundamentos, n² 2, 2000, pp. 359-457.

Fioravanti, Maurizio, Los derechos fundamentales: apuntes de historia de las constituciones, Trotta, Madrid, 1998.

García Pelayo, Manuel, "Del mito y de la razón en el pensamiento politico", Revista de Occidente, Madrid, 1968.

García Villegas, Mauricio, "Apuntes sobre codificación y costumbre en la historia del derecho colombiano", Opinión Jurídica, vol. 4, n 8, 2005, pp. 53-71.

Gardinetti, Juan Paulo, La revolución criolla: surgimiento y desarrollo de las instituciones argentinas en la etapa revolucionaria (1810-1815), Universidad Nacional de la Plata, La Plata, 2006, pp. 25-28.

Garrido, Margarita y Luz, Martha, "Pueblo - Colombia", en Javier Fernández Sebastián (Dir.), Diccionario politico y social del mundo iberoamericano, La era de 
las revoluciones, 1750-1850, Iberconceptos I, Fundación Carolina y otros, Madrid, 2009, pp. 1176-1189

González Cruz, David, Prácticas religiosas y mentalidad social en la Huelva del siglo XVIII, Universidad de Huelva, Huelva (España), 1999 (edición electrónica).

Gramsci, Antonio, La formación de los intelectuales, Grijalbo, México, 1967.

Hegel, Jorge Guillermo Federico, Lecciones Sobre la Filosofía de la Historia Universal (1830), Revista de Occidente, Madrid, 1952.

Hernández, José, "Martín Fierro", en Martín Hernández et. al., Martín Fierro. Informe de Brodie. El perseguidor, La oveja negra, Bogotá, 1987, pp. 9-206.

Jaramillo Uribe, Jaime, El pensamiento colombiano en el siglo XIX, Planeta, Bogotá, 1996.

Kant, Immanuel, Filosofía de la historia, Fondo de Cultura Económica, Bogotá, 1994.

König, Hans-Joachim, "Ciudadano - Colombia", en Javier Fernández Sebastián (Dir.), Diccionario politico y social del mundo iberoamericano, La era de las revoluciones, 1750-1850, Iberconceptos I, Fundación Carolina y otros, Madrid, 2009, pp. 234-246.

König, Hans-Joachim, "Nación - Colombia", en Javier Fernández Sebastián (Dir.), Diccionario político y social del mundo iberoamericano, La era de las revoluciones, 1750-1850, Iberconceptos I, Fundación Carolina y otros, Madrid, 2009, pp. 906918.

Labra, Rafael María de, América y la Constitución española de 1812: La Cortes de Cádiz de 1810-1813, Tipografia del Sindicato de la Publicidad, Madrid, 1914.

Lima Barreto, Afonso, Triste fim de Policarpo Quaresma (1911), Ática, São Paolo, 2004.

Lomné, Georges, "De la "república" y otras repúblicas: la regeneración de un concepto", en Javier Fernández Sebastián (Dir.), Diccionario politico y social del mundo iberoamericano, La era de las revoluciones, 1750-1850, Iberconceptos I, Fundación Carolina y otros, Madrid, 2009, pp. 1253-1269.

Lomné, Georges, "República - Colombia", en Javier Fernández Sebastián (Dir.), Diccionario político y social del mundo iberoamericano, La era de las revoluciones, 1750-1850, Iberconceptos I, Fundación Carolina y otros, Madrid, 2009, pp. 13061320.

López Bohórquez, Alí Enrique, "Viejas instituciones para una nueva república: El caso de Venezuela (1810-1830)", Revista de Historia del Derecho, n³2, 2004, pp. 135-148.

López-Domínguez, Virginia, "Sobre la evolución de la filosofía kantiana de la historia", Logos, Anales del seminario de metafisica, n 37, 2004, pp. 89-110.

Lucas, Javier de, "Racismo y xenofobia: la respuesta del derecho", en Sami Naïr y Javier de Lucas, El desplazamiento en el mundo: Inmigración y temáticas de identidad, Ministerio de Trabajo y Asuntos Sociales, Madrid, 1998, pp. 89-124.

Lynch, John, Hispanoamérica 1750-1850: Ensayos sobre la sociedad y el Estado, Universidad Nacional de Colombia, Bogotá, 1987. 
Mejía, Sergio, La revolución en letras: La historia de la revolución de Colombia de José Manuel Restrepo (1781-1863), Universidad de los Andes y Universidad EAFIT, Bogotá-Medellín, 2007.

Melo, Jorge Orlando, "Historia - Colombia" en Javier Fernández Sebastián (Dir.), Diccionario politico y social del mundo iberoamericano, La era de las revoluciones, 1750-1850, Iberconceptos I, Fundación Carolina y otros, Madrid, 2009, pp. 616627.

Montesquieu, Del espiritu de las leyes, Altaza, España, 1993.

Morillo, Pablo, Memorias (1826), Incunables, Bogotá, 1991.

Múnera, Alfonso, El fracaso de la nación: región, clase y raza en el Caribe colombiano (1717-1810), Banco de la República y El Áncora editores, Bogotá, 1998.

Mutis, José Celestino, El Arcano de la Quina [1828]. Cádiz: Diputación de Cádiz, 2008. Facsimil.

Peralta, Jaime Andrés, Los novatores: la cultura ilustrada y la prensa colonial en Nueva Granada (1750-1810), Editorial Universidad de Antioquia, Medellín, 2005.

Pérez Collados, José María, "La recepción de los principios politicos de la ilustración en la Nueva España", en Homenaje al profesor Alfonso García-Gallo, Tomo III, vol. 2, Universidad Complutense, Madrid, 1996, pp. 227-259.

Portillo Valdés, José María. "Cuerpo de nación, pueblo soberano. La representación politica en la crisis de la monarquía hispana", Ayer, No. 61, 2006, pp. 47-76.

Portillo Valdés, José María. "Nación - España", en Javier Fernández Sebastián (Dir.), Diccionario politico y social del mundo iberoamericano, La era de las revoluciones, 1750-1850, Iberconceptos I, Fundación Carolina y otros, Madrid, 2009, pp. 919-928.

Portillo Valdés, José María, Revolución de nación: orígenes de la cultura constitucional en España, 1780-1812, Centro de estudios políticos y constitucionales, Madrid, 2000.

Quintero, Inés y Martínez, Armando, Actas de formación de juntas y declaraciones de independencia (1809-1822), UIS, Bucaramanga, 2008, Tomo I y II.

Quintero Saravia, Gonzalo M, Pablo Morillo: General de dos mundos, Planeta, Bogotá, 2005.

Restrepo Toro, Hernando, "La educación superior", en Jorge Orlando Melo, Historia de Antioquia, Presencia, Bogotá, 1998, pp. 367-372.

Rodríguez, Mario, El experimento de Cádiz en Centroamérica, 1808-1826, Fondo de Cultura Económica, México, 1984.

Romero, José Luis, Situaciones e ideologías en América Latina, Universidad de Antioquia, Medellin, 2001.

Rousseau, Jean Jacques, El contrato social, Porrúa, México, 1998.

Sá e Melo Ferreira, Fátima, "Entre viejos y nuevos sentidos: "pueblo" y "pueblos" en el mundo iberoamericano entre 1750 y 1850", en Javier Fernández Sebastián (Dir.), Diccionario político y social del mundo iberoamericano, La era de las 
revoluciones, 1750-1850, Iberconceptos I, Fundación Carolina y otros, Madrid, 2009, pp. 1117-1138.

Sánchez, Bella Ismael, "Documentos vaticanos sobre la recopilación de Indias de 1680", Historiografia y bibliografia americanistas, EEHA-Sevilla, vol. XXXI, $n^{\circ} 1$, 1987, pp. 63-80.

Schallman, Lázaro, Diccionario de hebraísmos y voces afines, Israel, Buenos Aires, 1952.

Thibaud, Clément "Formas de guerra y construcción de identidades politicas: la Guerra de Independencia (Venezuela y Nueva Granada 1810-1825)", Análisis Politico, no 45, 2002, pp. 35-44.

Uribe Urán, Víctor, "Constitución - Colombia", en Javier Fernández Sebastián (Dir.), Diccionario politico y social del mundo iberoamericano, La era de las revoluciones, 1750-1850, Iberconceptos I, Fundación Carolina y otros, Madrid, 2009, pp. 364-373.

Uribe Vargas, Diego, Las constituciones de Colombia Tomo I, Cultura Hispánica, Madrid, 1977.

Varela Suanzes, Joaquín, La teoría del Estado en los origenes del constitucionalismo hispánico (las Cortes de Cádiz), Centro de Estudios Constitucionales, Madrid, 1983.

Velásquez, Érika, "La religión católica en las constituciones neogranadinas de 1811 a 1815", Revista Facultad de Derecho y Ciencias Políticas, vol. 36, n 105, 2006, pp. 283-298.

Voltaire, Tratado de la tolerancia, Crítica, Barcelona, 1977.

Wasserman, Fabio, "El concepto de nación y las transformaciones del orden politico en Iberoamérica, 1750-1850", en Javier Fernández Sebastián (Dir.), Diccionario político y social del mundo iberoamericano, La era de las revoluciones, 1750-1850, Iberconceptos I, Fundación Carolina y otros, Madrid, 2009, pp. 851-869.

Weil, Simone, Raices del existir -preludio a una declaración de deberes hacia el ser humano (1943), Sudamericana, Buenos Aires, 1954.

Enviado el (Submission Date): 03/04/2017

Aceptado el (Acceptance Date): 23/06/2017 